PHAST TRANSFORMATIONS IN NICKFL-BASE SUPERALIOYS

J. R. Mihalisin and D. I. Pasquine

Abstract

A study has been made of the phase transformations that occur during long time rupture testing of IN-731X, an alloy specifically designed for phase stability. No sigma formation was observed in this alloy.

The beneficial effect of heat treatment in inhibiting sigma formation and the anomalous effect of heal treatment on the rupture properties of alloy $713 \mathrm{C}$ and a11oy $713 \mathrm{LC}$ have been correlated with microstructural alterations induced by heat treatment.

A method for electron vacancy calculation has been devised which incorporates the actual $\gamma^{\prime}$ chemistry obtained by preferential extraction techniques and chemical analysis. This method is used to show that long time rupture testing and heat treatment have little effect on electron vacancy number.

J. R. Mihalisin and D. I. Pasquine are with The International Nickel Company, Inc., Paul D. Merica Research Laboratory, Sterling Forest, Suffern, New York 10901 
INTRODUCTTON

A recent study(I) has shown how compositional modification of IN 100 alloy leads to freedom from sigma formation. A new alloy, IN-73IX, has been developed which incorporates these changes without sacrificing IN 100 alloy properties.

The above study also revealed that a certain heat treatment reduced sigma susceptibility in alloy $713 \mathrm{C}$ and alloy 713LC. However, this treatment had an anomalous effect on properties; being beneficial for alloy $713 \mathrm{LC}$, but detrimental to alloy $713 \mathrm{C}^{\prime} \mathrm{s} 1500^{\circ} \mathrm{F}$ rupture strength.

In the present study, the phase transformations in IN -73 IX have been delineated. The effect of heat treatment on the phase transformations and phase morphology in alloys $713 \mathrm{C}$ and $713 \mathrm{LC}$ have been correlated with properties. The electron vacancy concept was used in these investigations but was extended beyond its usual simplifying assumptions by employing actual $\gamma^{\prime}$ phase compositions.

EXPERIMENTAL PROCEDURE

Phase transformations were studied by light and electron microscopy and $\mathrm{x}$-ray diffraction.

Specimens for light microscopic examination were prepared by conventional grinding and polishing followed by etching with glyceregia (2:I $\mathrm{HCl}_{1} / \mathrm{HNO}_{3}+3$ glycerine by volume). Photomicrographs of stress rupture specimens were taken adjacent to the fracture.

Negative replicas for electron microscopy were taken from surfaces electropolished with a solution of $15 \% \mathrm{H}_{2} \mathrm{SO}_{4}$ in methanol and etched in glyceregia.

$$
\text { X-ray diffraction studies of carbide phases were }
$$
made from residues electrolytically extracted in 10\% $\mathrm{HCl}$ in methanol. The $\gamma^{\prime}$ phase was electrolytically extracted in a solution of $20 \% \mathrm{H}_{3} \mathrm{PO}_{4}$ in $\mathrm{H}_{2} \mathrm{O}$ and was shown, by $\mathrm{x}$-ray diffraction examination, to be free of contamination from other phases. The composition of the $\gamma^{\prime}$ phase was determined by wet chemical analysis. X-ray diffraction studies were made with iron-filtered CoKa radiation. X-ray patterns were recorded using a goniometer speed of $1 / 2 \%$ minute. The scintillation counter and pulso hei.ght analyzer operated at a channel height of 10 volts and a channel width of 12 volts. The equipment was calibrated with a powdered gold standard. 
RESULTS AND DISCUSSION

\section{Alloy IN $-731 \mathrm{X}$}

The results of stress rupture tests on IN-73IX in the temperature range of $1350^{\circ} \mathrm{F}$ to $1900^{\circ} \mathrm{F}$ are shown in Figure 1. The material was tested as cast and with two grain sizes. The coarse grains averaged $1 / 4 "$ diameter while the fine grains averaged 1/8" in diameter. The chemical composition of this heat is given in Table I which also shows the compositions of the other heats used in this study.

A compilation of the various phases electrolytically extracted from some of the test specimens of Figure 1 is given in Table II. In the "as cast" condition the major secondary phase is . MC carbide with a lattice parameter equal to $4.30 \AA$. This value is in excellent agreement with previous parameter data for pure TiC (2). The major phase change taking place in the alloy is a gradual formation of $\mathrm{M}_{2}{ }_{3} \mathrm{C}_{6}$ carbide in the temperature range of $1350^{\circ} \mathrm{F}$ to $1900^{\circ} \mathrm{F}$. This change is timetemperature dependent. At $1350^{\circ} \mathrm{F} \mathrm{M}_{2} \mathrm{C}_{6}$ formation takes a longer time than at $1900^{\circ} \mathrm{F}$. Also, at least as shown by the data at $1800-1900^{\circ} \mathrm{F}$, the $\mathrm{M}_{2}{ }_{3} \mathrm{C}_{6}$ carbide forms at the expense of the MC carbide. There is little change in the lattice parameters of these phases under the test conditions employed. In addition, the phase transformations are identical in both coarse- ard fine-grained alloys.

Figure 1 shows that the coarse grain condition results in a higher rupture strength in the 1800 to $1900^{\circ} \mathrm{F}$ region; the effect becoming most prominent at $1900^{\circ} \mathrm{F}$. At $1700^{\circ} \mathrm{F}$ the fine grain alloy has a higher rupture strength whereas little effect of grain size on strength is noticed at 1350 and $1500^{\circ} \mathrm{F}$. The grain boundary morphology is similar for both coarse and fine grain alloys as shown by the micrographs of Figure 2 for specimens tested at $1800^{\circ} \mathrm{F}$. It seems likely therefore that the higher strength of the coarse grain material at higher temperature is simply a grain size effect unrelated to the phase transformations taking place.

An electron vacancy computation, $\overline{\mathrm{N}}_{\mathrm{V}}$ (ref), yields a value of 2.31. This method of $\bar{N}_{V}$ computation is givon in Appendix I and will be referred to as $\vec{N}_{V}$ (ref) throughout this discussion. This method of electron vacancy computation has been agreed upon as the standard method to be used for comparison purposes at the International Symposium on Structural Stability at Seven Springs, Pennsylvania. ( $\overline{\mathbb{N}}_{V}$ (ref) values for the alloys are listed in Table $I)$. Alloys with $\bar{N}_{V}$ numbers less than about 2.50 are considered not to be prone to sigma formation. However, sigma has been found in alloys of the Alloy 713C type with $\bar{N}_{V}$ numbers as low as $2.10(1)$. No sigma was detected in the IN-731X alloy studied here. 
The most questionable assumption made in conventional $\overrightarrow{\mathbb{N}}_{\mathrm{V}}$ computations lies in the treatment of the $\gamma^{\prime}$ precipitation. First of all, it is usually assumed that all aluminum and titanium in the alloy is used to form $\gamma^{\prime}$, (Nis (Al, Ti)). From a consideration of simple Ni-Al-Ti alloys(3) (upon which system complex superalloys are based), it can readily be seen that aluminum and titanium are actualiy partitioned between the $\gamma$ and $\gamma^{\prime}$ phases as $\gamma^{\prime}$ precipitates from $\gamma$. In addition, the $\gamma^{\prime}$ phase in superalloys has some solubility for many other alloying additions, as demonstrated by Guard and Westbrook(4). When these effects are taken into account, it is clear that the residual matrix composition would differ from that obtained by assuming that $\gamma^{\prime}$ is simply $\mathbb{N i s}$ (Al, Ti) and that it consumes the total aluminum-titanium content of the alloy. This, of course, would markedly affect the $\overline{\mathbb{N}}_{V}$ number of the alloy, since the residual matrix composition after precipitation has taken place is used to calculate this number.

The chemical composition (in atomic percent) of the $\gamma^{\prime}$ phase extracted from an as-cast specimen of IN-73IX is given in Table III. The results are an average of two separate determinations. The mean deviation of these from the average is also given. The largest variations are in the aluminum and titanium contents, and this is probably an indication of microsegregation. As can be seen, the $\gamma^{\prime}$ phase has solubility for a number of elements. Earlier work (4) indicated that cobalt would inhabit nickel sites in the $\gamma^{\prime}$ ( $\left.N i_{3} A l\right)$ phase, while $\mathrm{Cr}$ and Mo would tend lo occupy both nickel and aluminum sites. Titanium and vanadium tend to occupy aluminum sites. Using this as a basis, a formula:

$$
\left(\begin{array}{lllllllll}
\mathrm{Ni} & \mathrm{Co} & \mathrm{Cr} & \mathrm{Mo} & \mathrm{Al} & \mathrm{Ti} & \mathrm{V} & \mathrm{Cr} & \mathrm{Mo} \\
.880 & .079 & .034 & .009 & .613 & .331 & .023 & .023 & .010
\end{array}\right.
$$

can be deduced for the $\gamma^{\prime}$ composition given in Table III. The distribution of chromium and molybdenum between nickel and aluminum sites above is not arbitrary. Measurements of the degree of long range order indicate that chromium and molybdenum inhabit nickel sites in a ratio of approximately four to one. Any remaining chromium and molybdenum occupy aluminum sites. In any event, this is not a critical point in the discussion to follow since it only affects the calculation of the density of the $\gamma^{\prime}$ phase and the effect is small because of the small amounts of chromium and molybdenum involvea.

Knowing the composition and volume percentage of $\gamma^{\prime}$ in the alloy and the density and composition of the alloy, a determination can be made of the residual matrix composition after $\gamma^{\prime}$ precipitates from $\gamma$. 
of the $i^{\text {th }}$ This is done in the following manner: the weight,

$$
\left(w_{i}\right)^{\gamma}=\left(w_{i}\right)^{\text {alloy }}-\left\{\left(w_{i}\right)^{\mathrm{Cr}_{21} \mathrm{MO}_{2} \mathrm{C}_{6}}+\left(w_{i}\right)^{\mathrm{TiC}}+\left(w_{i}\right)^{\gamma^{\prime}}\right\}
$$

where $i=\mathrm{Cr}$, Co, Mo, V, Ti, $\mathrm{Al}$, and $\mathrm{Ni}$

$$
\begin{aligned}
& \left(W_{i}\right)^{\text {alloy }}=p_{\text {alloy }} \times \text { (unit vol) } \times \begin{array}{r}
\text { (weight percent of } \\
\text { element in alloy) }
\end{array} \\
& \rho_{\text {alloy }}=\text { density of alloy }
\end{aligned}
$$

$\left(W_{j}\right)^{\mathrm{Cr}_{2} \mathrm{MO}_{2} \mathrm{C}_{6}}$ and $\left(W_{i}\right)^{\mathrm{TiC}}$ are weights of respective carbides assuming all carbon is converted to carbide and evenly divided between the two varieties.

$$
\begin{aligned}
& \left.\left(w_{i}\right)^{\gamma^{\prime}}=\rho_{\gamma^{\prime}} \times \text { (volume percent } \gamma^{\prime}\right) \times\left(\begin{array}{l}
\text { weight percent of } \\
\left.i \text { element in } \gamma^{\prime}\right)
\end{array}\right. \\
& \rho_{\gamma^{\prime}}=\text { density of } \gamma^{\prime} \text {; } \\
& \rho_{\gamma^{\prime}}=\frac{\sum_{i} t_{h} \text { atoms on nickel sites } x \text { (atomic weight) } i+}{\text { Avogadro's Number } x a_{0}{ }^{3}} \\
& a_{0}=\text { lattice parameter } \\
& \text { of } \gamma^{\prime} \text { phase }
\end{aligned}
$$

weight percent of $i^{\text {th }}$ element in $\gamma=\frac{\left(w_{i}\right)^{\gamma}}{\sum\left(w_{i}\right)^{\gamma}}$

The weight percent of each element is converted to atomic percent and the formula for $\overline{\mathrm{N}}_{\mathrm{V}}$ is calculated as usual:

$$
\overline{\mathrm{N}}_{\mathrm{V}}=\sum_{\mathrm{m}} \text { (atomic percent) ith element } \mathrm{x}\left(\overline{\mathrm{N}}_{\mathrm{V}}\right) \mathbf{i}
$$

Using $\rho$ alloy $=7.75 \mathrm{~g} / \mathrm{cm}^{3}$, ao $=3.58 \AA$ and vol $\% \gamma^{\prime}=58.4$ as measured on electron micrographs yields a value of $\overrightarrow{\mathrm{N}}_{\mathrm{v}}=2.07$ which is significantly lower than the $\overline{\mathrm{N}}_{\mathrm{v}}$ (ref) value of 2.31 .

It was noticed in making this calculation that the amount of titanium left in the residual matrix after precipitation was reduced virtually to zero. This suggested a method of determining the volume percent of the $\gamma^{\prime}$ in this alloy without recourse to laborious lineal analysis of micrographs. This could be done by using the relation: 


$$
\left(W_{i}\right)^{\gamma^{\prime}}=p_{\gamma^{\prime}}\left(\text { volume percent } \gamma^{\prime}\right) \times\left(\begin{array}{l}
\text { weight percent of } \\
\text { ith element in the } \left.\gamma^{\prime}\right)
\end{array}\right.
$$

Assuming all titanium is consumed by $\gamma^{\prime}$ except that amount precipitated as Tic gives:

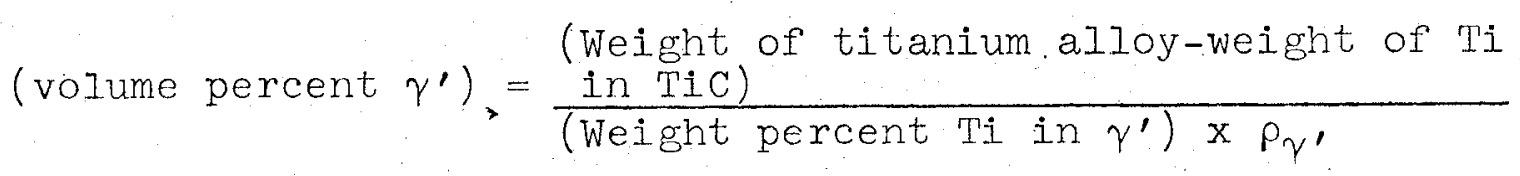

As seen in Table III, tho volume percent $\gamma^{\prime}$ calculated from such determinations yields an average value of $58.9 \pm 3.8 \%$ which is in excellent agreement with the observed value of 58.4\%. A typical area of the "as cast". structure is shown in Figure 3.

The average $\overline{\mathbb{N}}_{\mathrm{V}}$ value calculated using the assumption that there is no Ti in the residual matrix is also given in Table III. It appears that the reproducibility obtainable for $\overline{\mathbb{N}}_{\mathrm{V}}$ by this method is about \pm 0.04 electron vacancy units. It should also be noted that an appreciable amount of aluminum is left in the residual matrix. Following the Pauling scheme, aluminum is given an $\overline{\mathbb{N}}_{\mathrm{V}}$ value of 7.66 units for calculation purposes.

Table IV compares the compositions of the $\gamma^{\prime}$ and the residual matrix of as-cast IN $731 \mathrm{X}$ with those of samples rupture tested at $1350^{\circ}, 1500^{\circ}$, and $1800^{\circ} \mathrm{F}$. The volume percent $\gamma^{\prime}$ calculated as shown above (no titanium in the residual matrix) and volume percent $\gamma^{\prime}$ measured from electron micrographs are shown along with $\overline{\mathbb{N}}_{V}$ numbers. A formula for $\gamma^{\prime}$ is given for each $\gamma^{\prime}$ composition on the basis discussed previously. It can be seen that there is excellent agreement between volume percent $\gamma^{\prime}$ calculated and volume percent $\gamma^{\prime}$ measured which shows that the assumption that titarium is reduced to zero in the residual matrix is a valid one. The $\overline{\mathbb{N}}_{V}$ numbers in Table IV have been calculated on the basis that titanium is reduced to zero in the residual matrix although there is very little difference (within \pm .02 electron vacancy units) if volume percent $\gamma^{\prime}$ observed is used instead in the calculations.

It is readily seen that, within experimental error, there is little variation in $\overline{\mathbb{N}}_{\mathrm{V}}$ number over a. wide range of temperature and stress conditions, and little variation of these from the as-cast value. The only exception is at $1500^{\circ} \mathrm{F}$ where the $\overline{\mathbb{N}}_{\mathrm{V}}$ number was slightly lower. It is thus reasonable to assume that $\overrightarrow{\mathbb{N}}_{\mathrm{V}}$ number for this alloy can be considered a constant over a wide range of time, temperature, and stress. 
It is also seen from the $\gamma^{\prime}$ formulas that vanadium tends to take up positions on nickel sites as the temperature of testing is increased. This could be the result of dissolution of TiC at the higher temperatures thus releasing titanium and depriving vanadium of aluminum sites which are now preferentially taken up by titanium. This is also reflected in the increase in titanium content of the $\gamma^{\prime}$ in the $1800^{\circ} \mathrm{F}$ test specimen. Also there is a decrease in the chromium content of the $\gamma^{\prime}$ phase particularly in the $1800^{\circ} \mathrm{F}$ test specimen where extensive $\mathrm{Cr}_{2}, \mathrm{MO}_{2} \mathrm{C}_{6}$ formation occurs (Table II) making less chromium available for the $\gamma^{\prime}$ phase. There is also a decrease in the volume fraction of $\gamma^{\prime}$ phase at $1800^{\circ} \mathrm{F}$. This would result in some diminution of strength.

II. Effect of Heat Treatment on AIIoy 713C and AIIoy 713IC

Previous study(1) of alloys $713 \mathrm{C}$ and $713 \mathrm{IC}$ has shown that heat treatment can affect subsequent sigma formation. This is illustrated by the data in Table V. It can be seen that, for those alloys which form sigma, a treatment of $2150^{\circ} \mathrm{F} /$ I $\mathrm{hr} .+1900^{\circ} \mathrm{F} / 4$ hours reduces the amount of sigma formed at $1500^{\circ} \mathrm{F}$.

The effect of heat treatment on the microstructure of alloy $713 \mathrm{C}$ is shown in Figure 4. The phases listed under the optical micrographs are the phases identified in electrolytic extraction residues. It is apparent that extensive $\mathrm{M}_{2}{ }_{3} \mathrm{C}_{6}$ carbide formation occurs after 4 hours at $1900^{\circ} \mathrm{F}$ while at $2150^{\circ} \mathrm{F}$, in onc hour, only a small amount of $\mathrm{M}_{6} \mathrm{C}$ carbide was formed; The combination treatment ( $2150^{\circ} \mathrm{F} / 1 \mathrm{hr} .+1900^{\circ} \mathrm{F}$ ) 4 hrs.) yielded both $\mathrm{M}_{23} \mathrm{C}_{0}$ and $\mathrm{M}_{3} \mathrm{C}$ carbides. The optical micrographs reveal some alteration in the $\gamma^{\prime}$ morphology in the $2150^{\circ} \mathrm{F}$ heat treated and doubly heat treated samples particularly near grain boundaries.

To study the alterations in morphology in detail of these phases after heat treatment, electron microscopy is necessary. Figure 5 compares the as-cast microstructure of alloy $713 \mathrm{C}($ area(a) ) with three areas observed after a treatment of $2150^{\circ} \mathrm{F}$ for one hour. In area(b) (near a grain boundary), it is apparent that much of the $\gamma^{\prime}$ has been dissolved by this treatment and reprecipitated in a "feathery" type distribution. In area(c), near MC carbides, the $\gamma^{\prime}$ has a somewhat different distribution but definitely shows evidence of solutioning and reprecipitation. In addition, initiation of precipitation of carbide, presumably $\mathrm{M}_{6} \mathrm{C}$, occurs around $\mathrm{MC}$ carbides. In area(d) the $\gamma^{\prime}$ has about the same distribution as in the as-cast condition, although this type of area is not as prevalerl as areas(b) and (c). This indicates that a short time at high temperature may not be sufficient to completely dissolve $\gamma^{\prime}$. 
A similar comparison of the microstructure aftex a treatment at $1900^{\circ} \mathrm{F}$ for 4 hours is shown in rigure 6 . In area(a), the $\gamma^{\prime}$ is similar in appearance to that in the ascast microstructure, although some has dissolved and reprecipitated. Area(b) shows agglomeration and reprecipitation of $\gamma^{\prime}$ similar to that in Figure 5(c). In area(c) extensive carbide formation around $M C$ carbides occurs. Also, although not shown here, there is extensive carbide formation at grain boundaries after this treatment. From the $\mathrm{x}$-ray diffraction data, it would appear that the major amount of this carbide is of the $\mathrm{M}_{2}{ }_{3} \mathrm{C}_{6}$ type.

The microstructure after the dual treatment (2150\% $\mathrm{F} /$ $1 \mathrm{hr} .+1900^{\circ} \mathrm{F} / 4 \mathrm{hrs.}$ ) is shown in Figure 7 . In area(a) $\mathrm{M}_{23} \mathrm{C}_{6}$ carbide has precipitated at a grain boundary and a wide swath of $\gamma^{\prime}$ has developed along the boundary. It is also seen that this grain boundary $\gamma^{\prime}$ is very likely different somewhat in composition from the $\gamma^{\prime}$ developed in the matrix as evidenced by the difference in elevation where cubical matrix $\gamma^{\prime}$ particles intersect grain boundary $\gamma^{\prime}$ showing a variation in etching behavior; hence, a difference in composition. The grain boundary $\gamma^{\prime}$ may be carbon rich, since $\gamma^{\prime}$ has some solubility for carbon as pointed out previously(5). In area(b), as one moves away from the grain boundary, there is a transition from the small cubical $\gamma^{\prime}$ particles to larger coarsened ones. Throughout the microstructure (areas a and $b$ ) there is very finely dispersed $\gamma^{\prime}$. The alteration in $\gamma$ ' morphology at grain boundaries as viewed optically (Figure 4 ) for this sample is thus the result of the fincr distribution of $\gamma^{\prime}$ adjacent to the boundary.

The effect of heat treatment on the microstructure of alloy 713LC is similar to that in alloy $713 \mathrm{C}$. Figure 8 shows the as-cast and heat treated microstructures at $500 \mathrm{X}$ magnification. The heat treatment produces alterations in $\gamma$ ' morphology which at low magnification occur as patches intergranularly near carbides and to a lesser degree near grain boundaries. At high magnification (Figure 9), typical areas of the as-cast and heat treated samples are shown. As-cast areas, (a) and (b), illustrate the different shapes of the $\gamma^{\prime}$ phase at different sections through the sample. After heat treatment, area(c) shows precipitation of $\mathrm{M}_{2} \mathrm{C}_{6}$ carbide and $\gamma^{\prime}$ at the grain boundary. The matrix $\gamma^{\prime}$ near the boundary is in a fine dispersion. Further away from the boundary, area(d); $\gamma^{\prime}$ has agglomerated and reprecipitated in a fine dispersion. Thus the microstructure after heat treatment is similar to that observed in alloy 713C. The major difference is one of degree. There is less carbide precipitation in alloy $713 \mathrm{LC}$ because of lower carbon content and less $\gamma^{\prime}$ is developed at grain boundaries because of this. 
The method of using $\gamma^{\prime}$ chemistry to determine $\overline{\mathbb{N}}_{\mathrm{V}}$ number as outlined previously for IN-73IX effectively allows $\overline{\mathrm{N}}_{\mathrm{V}}$ to become a function of time and temperature rather than being only a function of the composition of the alloy. It was decided to apply this method to 7130 to determine whether $\bar{N}_{V}$ could be correlated with the beneficial ef'ect of heat treatment in inhibiting sigma formation. The computations were made in the same way as outlined for IN-73IX except that the carbides were assumed to be $(\mathrm{Cb}, \mathrm{Ti}) \mathrm{C}$ and $\mathrm{Cr}_{2} \mathrm{MO}_{2} \mathrm{C}_{6}$. In the case of alloy $713 \mathrm{C}$, it was found that columbium was reduced virtually to zero in the residual matrix so that volume percent $\gamma^{\prime}$ could be obtained by using the columbium contents of the $\gamma^{\prime}$ and the alloy. Titanium is also reduced to small amounts in the residual matrix but the amount remaining is not quite negligible. These data for as-cast alloy $713 \mathrm{C}$ and in three conditions of heat treatment are given in Table VI in an analogous manner to that shown for IN-73IX (Table IV). The $\gamma^{\prime}$ formula was deduced in the same way as for IN-73IX. Again $\mathrm{x}$-ray long range order measurements showed that the chromium and molybdenum distribution on nickel and aluminum sites was similar to that of the $\gamma^{\prime}$ extracted from IN-731X. The excelient agreement between volume percent $\gamma^{\prime}$ calculated, assuming columbium reduced to zero in the matrix, and volume pcrcent $\gamma^{\prime}$ measured attests to the validity of this assumption.

The $\overline{\mathbb{N}}_{V}$ value for Heat 85 in the as-cast condition is 2.20 (Table VI) which is somewhat higher than that for $\overline{\mathrm{N}}_{\mathrm{V}}$ (ref) of 2.12 but the discrepancy is not as great as with IN-731X. This is due to the fact that the assumption that all the columbium and titanium is tied up as $\gamma^{\prime}$ is not too far removed from what really occurs in alloy $713 \mathrm{C}$. Although not all the aluminum is tied up as $\gamma^{\prime}$, this is comperisated for by the greater amount of nickel left in the residual matrix. The values of the $\overline{\mathbb{N}}_{Y}$ numbers for aluminum and nickel and the amount of partilioning of aluminum between $\gamma$ and $\gamma^{\prime}$ ' are such as to be very nearly compensating in their effect on $\overline{\mathrm{N}}_{\mathrm{V}}$. These compensating effects would not be expected to hold true for all alloys as was shown for IN $-731 X$.

There is very little variation of $\overline{\mathbb{N}}_{V}$ values, within experimental error, with heat treatment (Table VI). The experimental error here is assumed to be about the same as with IN-73IX, i.e., $\pm .04 \overline{\mathbb{N}}_{\mathrm{V}}$ units. Thus this type of electron vacancy calculation does not serve as an indicator for the influence of heat treatmont on sigma formation.

The influence of heat treatment on sigma formation in both $713 \mathrm{C}$ and $713 \mathrm{LC}$ can be rationalized to some extent on the basis of the previous microstructural observations. Two effects occur as these alloys are heat treated in the 1900$2150^{\circ} \mathrm{F}$ regions. There is solutioning of $\gamma^{\prime}$ and precipitation of $\mathrm{M}_{23} \mathrm{C}_{6}$ and $\mathrm{M}_{6} \mathrm{C}$ carbides. The preponderant carbide is $\mathrm{M}_{23} \mathrm{C}_{6}$ at $1900^{\circ} \mathrm{F}$ and at $2150^{\circ} \mathrm{F}$ a small amount of $\mathrm{M}_{6} \mathrm{C}$ and no $\mathrm{M}_{23} \mathrm{C}_{6}$ forms. With solutioning of $\gamma^{\prime}$ there is undoubtedly a general 
homogenization of the alloy. This in itself would tend to reduce sigma forming tendency of an alloy in which sigma forming elements had segregated.

The carbides, particularly $\mathrm{M}_{2} 3 \mathrm{C}_{6}$ which forms in largest quantities upon heat treatment, contain chromium and molybdenum which are effective elements in forming the Ni-CrMo type sigma observed in this alloy. Thus an alloy which is marginally sigma-prone or macro-segregated can be made less so by precipitation of such carbides, thereby reducing the effective matrix content of the alloy in chromium and molybdenum. There is a seeming paradox here since sigma often nucleates on such carbides in the sigma forming rogion(I). It is possible that the $\mathrm{M}_{23} \mathrm{C}_{6}$ carbides formed upon heat treatment at $1900^{\circ} \mathrm{F}$ differ in composition from those formed at lower temperatures, possibly being richer in molybdenum which has been shown to be a more effective contributor to sigma formation than its normally assigned value of 4.66 would indicate(1). Even assuming no composition difference in the carbides at these temperatures there would be a balance between the matrix composition, amount and distribution of the carbide formed and sigma forming tendency. In this case it would be possible for carbide precipitation either to inhibit or promote sigma formation. The latter effect would occur in an alloy that was extremely prone to sigma formation so that precipitation of carbide would be insufficient to reduce the sigma forming tendency of the matrix to a large extent. The carbides formed upon heat treatment would then act as nuclei for sigma precipitation.

It will he noticed in Table $\mathrm{V}$ for alloy 713LC that, in two heats (07 and 17) of material of practically identical. $\overline{\mathrm{N}}_{\mathrm{V}}$ (ref) number, one formed sigma and one did not. In fact, the non-sigma heat had a higher $\overline{\mathrm{N}}_{\mathrm{V}}$ (ref) than the sigma heat. It was decided to apply the method of $\overline{\mathrm{N}}_{\mathrm{V}}$ calculation developed here using $\gamma^{\prime}$ composition to determine whether this method would serve as a better indicator for sigma precipitation. The results are giver in Table VII in the same manner as for alloy $713 \mathrm{C}$. It can be seen that within experimental error, the $\bar{N}_{v}$ numbers are the samo for both heats. In fact, non-sigma heat had a higher $\overline{\mathrm{N}}_{V}$ number as was the case with $\overline{\mathrm{N}}_{\mathrm{V}}$ (ref) (Table $\mathrm{V})$. The concentration of $\mathrm{Cb}$ in the residual matrix is reduced virtually to zero as was the case with alloy $713 \mathrm{C}$ as shown by the good agreement of volume percent $\underline{\gamma}^{\prime}$ calculated with that of volume percent $\gamma^{\prime}$ measured. The $\overline{\mathrm{N}}_{\mathrm{V}}$ (ref) value for alloy 7I3LC is smaller than for alloy $713 \mathrm{C}$ due to the lower chromium content of the alloy 713IC heats. However, when using the $\overline{\mathbb{N}}_{V}$ calculation based on $\gamma^{\prime}$ composition it is seen that alloys $713 \mathrm{C}$ and '(13LC, have about the same $\overline{\mathrm{N}}_{\mathrm{V}}$ value. These $\overline{\mathbb{N}}_{\mathrm{V}}$ values are still rather low for what is generally experienced in practice where $\overline{\mathbb{N}}_{V}$ break-off values of 2.50 for sigma formation are usually found. The rationalization for this is that 
molybdenum, in this particular system, has a higher $\overline{\mathbb{N}}_{\mathrm{V}}$ value than is commonly assigned (I). Using an $\bar{N}_{V}$. value of 9.66 as developed in (I) yields $\bar{N}_{\mathrm{V}}$ 's for alloy $713 \mathrm{IC}$ of about 2.40 2.45 for $\overline{\mathbb{N}}_{\mathrm{V}}$ calculations using actual $\gamma^{\prime}$ compositions. This places the alloy nearer the 2.50 break-off value than $\overline{\mathrm{N}}_{\mathrm{Y}}$ (ref) where using $\overline{\mathrm{N}}_{\mathrm{V}}=9.66$ for molybdenum yields $\overline{\mathbb{N}}_{\mathrm{V}}$ 's for alloy 713 LC of about $2.25-2.30$.

It will be noticed (Table V) that although the heat. treatment of alloy $713 \mathrm{C}\left(2150^{\circ} \mathrm{F}+1900^{\circ} \mathrm{F}\right)$ reduces the tendency to develop sigma, this heat treatment does not appear to have exerted a useful effect on rupture properties at $1500^{\circ} \mathrm{F}$. A study was made of these individual heat treatments on structure and these results are shown in Figure 10. As can be seen, each individual heat treatment has reduced the tendency to form sigma, if one ignores the different times at temperature which are not appreciable.

In any evont, it is obvious that the rupture properties are not influenced to a great extent by the amount of sigma present. Rather, rupture life correlates with the amount of grain boundary $\gamma^{\prime}$ developed in these samples. Little of this grain boundary $\gamma^{\prime}$ is developed in the as-cast alloy which had the longest rupture life. More is developed in the heat treated samples, all of which had lower lives than the as-cast material. The greatest amount of $\gamma^{\prime}$ formed in the specimen which had been given a dual treatment and which had the lowest life. The previous microstmuctural studies indicate that this is the result of carbide precipitation at grain boundaries during heat treatment. This induces grain boundary $\gamma^{\prime}$ formation. It is possible that the large amount of sigma developed in the as-casl sample prevented precipitation of grain boundary $\gamma^{\prime}$ and so increased strength.

On the other hand the data: of Table $V$ show that the same heat treatment for alloy $713 \mathrm{LC}$ produces an increasc in rupture life at $1500^{\circ} \mathrm{F}$ over the as-cast material. It will also be noticed that the heat with the lowest carbon level (Table I) benefited the most strengthwise from heat treatment. An optical micrograph of this heat is shown in Figure 11 after the 3600-hour test (heat treated condition). It will be seen that little agglomerated $\gamma^{\prime}$ can be detected at this magnification at grajn boundaries unlike the case for heat treated alloy $713 \mathrm{C}$ (Figure 10). It is possible that there is an optimum amount of carbide precipitated at grain boundaries that is useful in increasing rupture strength. However, heat treatment does homogenize and refine the $\gamma^{\prime}$ structure which could also be a strengthening mechanism as has been already suggested(5). This strengthoning effect could compensate for any weakening effect carbides might have at grain boundaries. In this case, an alloy. with as low carbon as possible would derive the greatest strength benefit from heat treatment. Some 
carbon might be useful as a means for inhibiting sigma formation by heat treatmont, however, and/or as a possible strengthening mechanism, through carbide precipitation upon heat treatment.

IIJ. Partitioning of Alloy Flements Between the $\gamma^{\prime}$ Phase and the Residual Matrix

The partitjoning of elements between $\gamma^{\prime}$ and residual matrix in IN-731X, A1loy $713 \mathrm{C}$ and Alloy 713LC is shown in Figure 12. The results shown are averages of all the delerminations for each alloy presented in this study since there was little significart varietion between the different samples from cach alloy. The average $\gamma^{\prime}$ composition for each of the alloys in formula form is as follows:

IN $731 \mathrm{X}$ (Ni Co $\mathrm{Cr}$ Mo $\mathrm{V}$ ) 3 (AI Ti V $\mathrm{Cr}$ Mo) $\begin{array}{lllllllll}.884 & .070 .032 & .008 & .003 & .632 & .347 & .013 & .006 & .002\end{array}$

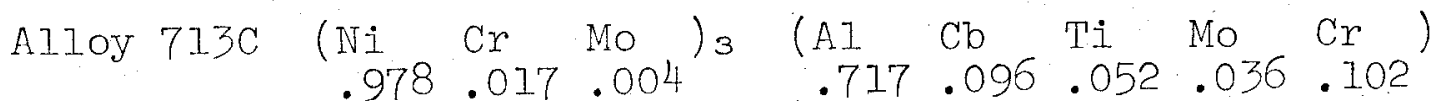

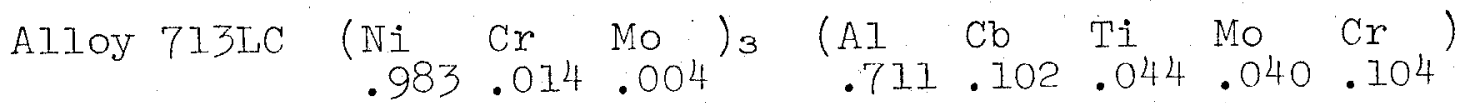

There is little difference between the $\gamma^{\prime}$ composition of alloys $713 \mathrm{C}$ and $713 \mathrm{IC}$ so that an average value can be used for both alloys as follows:

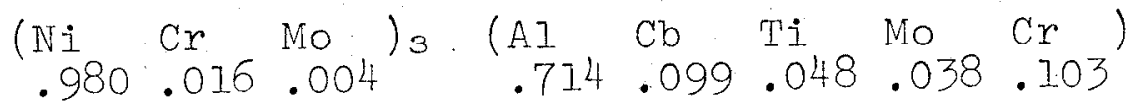

Nickel (Figure 12) is preferentially concentrated in the $\gamma^{\prime}$ phase for all three alloys, but a large amount remains in the residual matrix. The absolute level is higher in $713 \mathrm{C}$ and $713 \mathrm{IC}$ than in $731 \mathrm{X}$ because of the cobalt present. Titanium is concentrated in the $\gamma^{\prime}$ phase in all three alloys but to $a$ greater extent in IN-73IX (practically all of it) than in alloys $713 \mathrm{C}$ and 713LC. Aluminum is concentrated in the $\gamma^{\prime}$ phase in all three alloys but a considerable fraction remains in the residual matrix. Vanadium is concentrated in the residual. matrix in IN-73ix but some is present in the $\gamma^{\prime}$ phase. Vanadium is not present in alloys $713 \mathrm{C}$ or $713 \mathrm{LC}$. Columbium is concentrated practically entirely in the $\gamma^{\prime}$ phase in 713C and 713IC. Columbium is not present in IN-731X. Molybdenum is concentrated in the residual matrix in all three alloys to about the same degree although some is also present in the $\gamma^{\prime}$ phase. (The absolute molybdenum level is higher in alloys $713 \mathrm{C}$ and $713 \mathrm{LC}$ than in the $I N-(3 \perp X)$. Cobalt is concentrated in the residual 
matrix in IN-73IX but a considerable amount is found in the $\gamma^{\prime}$ phase. No cobalt is present in alloys $713 \mathrm{C}$ and $713 \mathrm{LC}$. Chromium is preferentially partitioned in the residual matrix although some is also present in the $\gamma^{\prime}$ phase.

Thus it can be seen that there is considerable solution of alloy elements in the $\gamma^{\prime}$ phase. As a consequence, since the sigma phase developed in alloys $713 \mathrm{C}$ and $713 \mathrm{LC}$ is of the Ni-Cr-Mo type, it would seem possible for sigma to form from these regions also. A calculation for $\overline{\mathrm{N}}_{\mathrm{V}}$ for the $\gamma^{\prime}$ phase based on the chemistry in Tables VI and VII for alloys $713 \mathrm{C}$ and $713 \mathrm{LC}$ gives values of about 2.30 which is higher than for the residual matrix(2.20). Of course, there is considerably less $M o$ and $\mathrm{Cr}$ in the $\gamma^{\prime}$ than in the residual matrix so this would tend to limit the amount of sigma that could be formed from these regions. However, sigma is often observed in these alloys growing through $\gamma^{\prime}$ areas as shown in Figure 13. Such growth can easily be rationalized by the above argument whereas simp Iy assuming $\gamma^{\prime}$ to be $\mathrm{Nis}$ ( $\mathrm{Al}, \mathrm{Ti}, \mathrm{Cb}, \mathrm{Ta}$ ) makes it difficult to see: how this situation could exist. 


\section{CONCIUUSIONS}

1. No sigma is observed in IN $-731 \mathrm{X}$ after Iong time testing in the region $1350-1900^{\circ} \mathrm{F}$.

2. Coarse grain. IN $-731 X$ has a higher rupture strength than fine grain in the region $1800-1900^{\circ} \mathrm{F}$. At $1700^{\circ} \mathrm{F}$ fine grain IN-73IX is somewhat stronger than coarse grain. In the $1350-1500^{\circ} \mathrm{F}$ range there is little effect of grain size on rupture strength.

3. Electron vacancy numbers obtained by using the actual $\gamma^{\prime}$ chemistry of IN-731X are less than those obtained by using simplified conventional calculations.

4. There is some variation in $\gamma^{\prime}$ chemistry of IN-73IX after long time testing in the region $1350-1800^{\circ} \mathrm{F}$, but the extent of the variation has little effect on electron vacancy number.

5. 'l'he beneficial effect of heat treatment in inhibiting sigma formation in alloys $713 \mathrm{C}$ and $713 \mathrm{LC}$ is attributed to homogenizalion and carbide precipitation upon heat treatment.

6. The detrimental effect of heat treatment on the $1500^{\circ} \mathrm{F}$ rupture properties of alloy $713 \mathrm{C}$ is attributed to grain boundary precipitation of $\gamma^{\prime}$ nucleated by carbide precipitation at the grain boundaries. This weakening effect overshadows any possible detrimental effect of sigma formation. It is possible that under some conditions sigma formation may actually enhance strength properties.

7. The beneficial effect of heat treatment on the $1500^{\circ} \mathrm{F}$ rupture properties of alloy $713 \mathrm{IC}$ is attributed to alteration of $\gamma^{\prime}$ morphology and lesser amount of carbide precipitation at grain boundarics upon heat treatment.

8. A simple method has been devised to estimate volume fraction of $\gamma^{\prime}$ phase in IN-73IX, a.110y 7I3IC and alloy 713C, knowing only the chemical composition of the $\gamma^{\prime}$ phase.

9. Electron vacancy calculations obtained by using $\gamma^{\prime}$ chemistry of alloys 713C and 713LC are higher than those obtained by using simplified conventional calculations. The amount of discrepancy is not as large as with IN-73IX.

10. The $\gamma^{\prime}$ phase in IN-73IX, alloy 713C and alloy 713LC shows extensive solubility for alloying elements including those involved in sigma formation. This circumstance 
rationalizes the common observation that sigma phase often grows through $\gamma^{\prime}$ regions.

11. The $\gamma^{\prime}$ composition for IN $-731 \mathrm{X}$ is (Ni.884 Co.070 $\mathrm{Cr} .032 \mathrm{Mo} .008 \mathrm{~V} .003)_{3}(\mathrm{Al} .632 \mathrm{Ti} .347 \mathrm{~V} .013 \mathrm{Cr} .006 \mathrm{Mo} .002$ l)

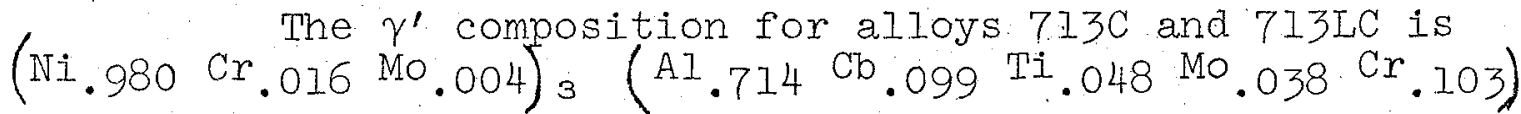

$J R M: D L P / K I C$

Copies to:

90

RSParmenter (77)
Technical Files (7)
RJRaudebaugh
RFDecker
CMDavis
CRCupp
DLPasquine
JRMihalisin

REFERENCES

1. J.R. Mihalisin, C.G. Bieher, R.T. Grant, "Sigma Its occurrence, Effect and Control in Nickel Base Superalloys," to be published.

2. H.J. Beattie, Jr., F.L. VerSnyder, "Microconsituents in High Temperature Alloys," Trans. ASM, Vol. 45, 1953 , p. 397 .

3. A. Taylor and R.W. Floyd, "The Constitution of Nickel-Rich Alloys of the Nickel-Titanium-Alumi
Joumal Inst. of Metals 1952, Vol. 81, p. 25.

4. R.W. Guard and J.H. Westbrook, "Alloying Behavior of $\mathrm{Ni} \mathrm{A}_{3} \mathrm{l}$ ( $\gamma^{\prime}$ phase)," Trans. AIME, Vol. 215, Oct. 1959, p. 807.

5. R.F. Decker and C.G. Bieber, "Microstructure of a Cast Age-Hardenable Nickel-Chromium Alloy," ASTM Spec. Tech. Publication No. 262, 1959, pp. 120-128. 


\section{APPENDIX I}

\section{REFERENCE METHOD FOR CALCULATION \\ OF EIECTRON VACANCY NUMBER ( $\bar{N}_{V}$ ref $)$}

1. Convert the composition from weight percent to atomic percent.

2. After long time exposure in the sigma forming temperature range the $\mathrm{MC}$ carbides tend to transform to $\mathrm{M}_{23} \mathrm{C}_{6}$.

a. Assume one-half of the carbon forms MC in the following preferential order: $\mathrm{TaC}, \mathrm{CbC}$, TiC.

b. Assume the remaining carbon forms $\mathrm{M}_{23} \mathrm{C}_{6}$ of the following composition: $\mathrm{Cr}_{21}(\mathrm{Mo}, \mathrm{W})_{2} \mathrm{C}_{6}$ or $\mathrm{Cr}_{23} \mathrm{C}_{6}$ in the absence of Mo or $\mathrm{W}$.

c. If the weight percent of $\mathrm{Mo}+\mathrm{W}>6.0$, then $\mathrm{M}_{6} \mathrm{C}$ of composition $\mathrm{NiCO}_{2}$ (Mo, $\left.W\right)_{3}$ forms in place of $\mathrm{M}_{23} \mathrm{C}_{6}$.

3. Assume boron forms $\mathrm{M}_{3} \mathrm{~B}_{2}$ of the following composition: (Mo0.5 Ti.o. $\left.{ }_{5} \mathrm{Cr}_{0.25} \mathrm{Ni0} .10\right)_{3} \mathrm{~B}_{2}$

4. Assume gamma prime to be of the following composition: $\mathrm{Ni}_{3}$ (AI, Ti, Ta, $\mathrm{CD}, \mathrm{Zr}, .03 \mathrm{Cr}^{*}$ )

* $(0.03 \%$ of the original atomic percent)

5. The residual matrix will consist of the atomic percent minus those atoms tied up in the carbide reaction, boride reaction, and the gamma prime reaction. The total of these remaining atomic percentages gives the atomic concentration in the matrix. Conversion of this on the $100 \%$ basis gives the atomic percent of each element remaining in the matrix. It is this percentage that is used in order to calculate the electron vacancy number.

6. The formula for calculation of the electron vacancy number is as follows:

$$
\begin{aligned}
\left(\overline{\mathbb{N}}_{\mathrm{V}} \mathrm{ref}\right) & =.66 \mathrm{Ni}+1.71 \mathrm{Co}+2.66 \mathrm{Fe}+3.66 \mathrm{Mn}+ \\
4.66(\mathrm{Cr}+\mathrm{MO}+\mathrm{W}) & +5.66 \mathrm{~V}+6.66 \mathrm{Si}
\end{aligned}
$$




\section{TABLE I}

Composition of Heats (weight percent) and $\bar{N}_{V}$ (ref) Numbers

\section{$I N-73 I X$}

$\frac{\text { Heat \# }}{77} \frac{\mathrm{C}}{.16} \frac{\mathrm{Cr}}{9.60} \frac{\mathrm{Co}}{9.72} \frac{\mathrm{Mo}}{2.46} \frac{\mathrm{V}}{.85} \frac{\mathrm{Ti}}{4.66} \frac{\mathrm{AI}}{5.60} \frac{\mathrm{B}}{.014} \frac{\mathrm{Si}}{.045} \frac{\mathrm{Fe}}{.23} \frac{\mathrm{Ni}}{66.936} \frac{\overrightarrow{\mathrm{N}}_{\mathrm{NI}}}{2}$

\section{Alloy $713 \mathrm{C}$}

\begin{tabular}{|c|c|c|c|c|c|c|c|c|c|c|}
\hline at \# & C & $\mathrm{Cr}$ & Mo & $\mathrm{Cb}+\mathrm{Ta}$ & $\mathrm{AI}$ & $\underline{T i}$ & B & $\mathrm{Ni}$ & $\underline{\mathrm{Si}}$ & $\mathrm{Fe}$ \\
\hline 74 & .13 & 12.94 & 4.46 & 2.21 & 6.14 & .81 & .010 & 73.300 & .04 & .1 \\
\hline 85 & .11 & 13.23 & 4.46 & 2.09 & 5.86 & .79 & .009 & 73.451 & .04 & 7 \\
\hline
\end{tabular}

\section{A110y $713 \mathrm{LC}$}

\begin{tabular}{|c|c|c|c|c|c|c|c|c|c|c|}
\hline eat \# & C & $\mathrm{Cr}$ & Mo & $\underline{\mathrm{Cb}+\mathrm{Ta}}$ & AI & $T i$ & B & $\mathrm{Ni}$ & S.i & Fe \\
\hline 07 & .06 & 12.32 & 4.46 & 2.13 & 5.90 & .72 & .009 & 74.401 & .05 & .20 \\
\hline 17 & .03 & 12.52 & 4.41 & 2.10 & 5.90 & .60 & .009 & 74.431 & $<.10$ & .15 \\
\hline
\end{tabular}




\section{TABIE II}

Phases Electrolytically Extracted From IN-73IX

\begin{tabular}{|c|c|c|c|c|c|}
\hline \multirow[b]{2}{*}{$\begin{array}{l}\text { Test } \\
\left.\text { emp ( }{ }^{\circ} \mathrm{F}\right) \\
\end{array}$} & \multicolumn{2}{|c|}{ Coarse Grain } & \multicolumn{3}{|c|}{ Fine Grain } \\
\hline & $\begin{array}{c}\text { Stress Rupture } \\
\text { Results } \\
\end{array}$ & $\begin{array}{l}\text { Phases Present and } \\
\text { Relative Abundarice* } \\
\end{array}$ & $\begin{array}{c}\text { Test } \\
\text { Temp }\left({ }^{\circ} \mathrm{F}\right) \\
\end{array}$ & $\begin{array}{c}\text { Stress Rupture } \\
\text { Results } \\
\end{array}$ & $\begin{array}{l}\text { Phases } \\
\text { Relativ }\end{array}$ \\
\hline- & As Cast & $M C\left(S-a_{0}=4.30\right)$ & - & As Cast & $M C\left(S-a_{0}\right.$ \\
\hline 900 & $\begin{array}{l}15,000 \mathrm{psi} \\
126.3 \mathrm{hrs} . \\
7.1 \mathrm{El}-7.0 \mathrm{RA}\end{array}$ & $\begin{array}{l}\operatorname{MC}\left(M-a_{0}=4.29\right) \\
M_{23} C_{6}\left(S-a_{0}=10.67\right)\end{array}$ & 1900 & $\begin{array}{l}15,000 \mathrm{psi} \\
92.0 \mathrm{hrs} . \\
7.1 \mathrm{EI}-11.7 \mathrm{RA}\end{array}$ & $\begin{array}{l}\mathrm{MC}\left(\mathrm{MS}-\mathrm{a}_{0}\right. \\
\mathrm{M}_{23} \mathrm{C}_{6}(\mathrm{~S}-\end{array}$ \\
\hline & $\begin{array}{l}10,000 \text { psi } \\
512.2 \text { hrs. } \\
2.7 \text { El }-6.7 \mathrm{RA}\end{array}$ & $\begin{array}{l}\operatorname{MC}\left(M-a_{0}=4.29\right) \\
M_{23} C_{6}\left(S-a_{0}=10.68\right)\end{array}$ & & $\begin{array}{l}8000 \text { psi } \\
603.9 \text { hrs. } \\
2.1 \text { El. - }\end{array}$ & $\begin{array}{l}\mathrm{MC}\left(\mathrm{MS}-\mathrm{a}_{0}\right. \\
\mathrm{M}_{23} \mathrm{C}_{6}(\mathrm{~S}-\end{array}$ \\
\hline 800 & $\begin{array}{l}20,000 \mathrm{psi} \\
264.7 \mathrm{hrs} . \\
9.7 \mathrm{El}-8.6 \mathrm{RA}\end{array}$ & $\begin{array}{l}M C\left(M S-a_{0}=4.30\right) \\
M_{23} C_{6}\left(S-a_{0}=10.69\right)\end{array}$ & 1800 & $\begin{array}{l}20,000 \text { psi } \\
194.2 \text { hrs. } \\
6.2 \text { El. }-8.0 \mathrm{RA}\end{array}$ & $\begin{array}{l}\mathrm{MC}\left(\mathrm{MS}-\mathrm{a}_{0}\right. \\
\mathrm{M}_{23} \mathrm{C}_{6}(\mathrm{~S}-\end{array}$ \\
\hline & $\begin{array}{l}15,000 \mathrm{psi} \\
942.1 \mathrm{hrs} . \\
5.3 \mathrm{Fl}-7.1 \mathrm{RA}\end{array}$ & $\begin{array}{l}\operatorname{MC}\left(M S-a_{0}=4.30\right) \\
M_{23} C_{6}\left(M S-a_{0}=10.70\right)\end{array}$ & & $\begin{array}{l}15,000 \mathrm{psi} \\
733.3 \mathrm{hrs} . \\
7.1 \mathrm{El}-13.7 \mathrm{RA}\end{array}$ & $\begin{array}{l}\mathrm{MC}\left(\mathrm{MS}-\mathrm{a}_{0}\right. \\
\mathrm{M}_{23} \mathrm{C}_{6}(\mathrm{MS}\end{array}$ \\
\hline .700 & $\begin{array}{l}40,000 \mathrm{psi} \\
38.6 \mathrm{hrs} . \\
4.5 \mathrm{EI}-7.0 \mathrm{RA}\end{array}$ & $\begin{array}{l}\mathrm{MC}\left(\mathrm{S}-2_{0}=4.29\right) \\
\mathrm{M}_{23} \mathrm{C}_{6}\left(\mathrm{MS}-\mathrm{a}_{0}=10.67\right)\end{array}$ & 1700 & $\begin{array}{l}40,000 \mathrm{psi} \\
54.0 \mathrm{hrs} . \\
8.9 \mathrm{El}-7.8 \mathrm{RA}\end{array}$ & $\begin{array}{l}\mathrm{MC}(\mathrm{MS}-8 \\
\mathrm{M}_{23} \mathrm{C}_{6}(\mathrm{~N}\end{array}$ \\
\hline & $\begin{array}{l}30,000 \mathrm{psi} \\
184.0 \mathrm{hrs} . \\
4.5 \mathrm{El}-6.3 \mathrm{RA}\end{array}$ & $\begin{array}{l}M C\left(M S-a_{0}=4.30\right) \\
M_{2}{ }_{3} C_{6}\left(N-a_{0}=10.69\right)\end{array}$ & & $\begin{array}{l}30,000 \mathrm{psi} \\
263.4 \mathrm{hrs} . \\
7.1 \mathrm{El} .-7.8 \mathrm{RA}\end{array}$ & $\begin{array}{l}\mathrm{MC}\left(\mathrm{S}-\mathrm{a}_{0}\right. \\
\mathrm{M}_{23} \mathrm{C}_{6}(\mathrm{MS}\end{array}$ \\
\hline & $\begin{array}{l}25,000 \mathrm{psi} \\
547.7 \mathrm{hrs} . \\
7.1 \mathrm{EI}-5.6 \mathrm{RA}\end{array}$ & $\begin{array}{l}M C\left(M S-a_{0}=4.30\right) \\
M 23 C_{6}\left(M_{1 S}-a_{0}=10.69\right)\end{array}$ & & $\begin{array}{l}25,000 \mathrm{psi} \\
612 \mathrm{hrs.} \\
8.1 \mathrm{E} 1.9 .3 \mathrm{RA}\end{array}$ & $\begin{array}{l}M C\left(M S-a_{0}\right. \\
M_{23} C_{6}(M c\end{array}$ \\
\hline & & & & $\begin{array}{l}20,000 \text { psi } \\
2102.4 \text { hrs. } \\
11.5 \text { El. - } 10.8 \mathrm{RA} \\
\text { Mihalisin }\end{array}$ & $\begin{array}{l}M C\left(S-a_{0}\right. \\
M_{2}{ }_{3} C_{6}(M E\end{array}$ \\
\hline
\end{tabular}


TABIE II (Cont)

\begin{tabular}{|c|c|c|c|c|c|}
\hline \multirow[b]{2}{*}{$\begin{array}{c}\text { Test } \\
\text { Temp }\left({ }^{\circ} \mathrm{F}\right) \\
\end{array}$} & \multicolumn{2}{|c|}{ Coarse Grain } & \multicolumn{3}{|c|}{ Fine Grain } \\
\hline & $\begin{array}{c}\text { Stress Rupture } \\
\text { Results } \\
\end{array}$ & $\begin{array}{l}\text { Phases Present and } \\
\text { Relative Abundance* } \\
\end{array}$ & $\begin{array}{l}\text { Test } \\
\text { Temp }\left({ }^{\circ} \mathrm{F}\right) \\
\end{array}$ & $\begin{array}{c}\text { Stress Rupture } \\
\text { Results } \\
\end{array}$ & $\begin{array}{l}\text { Phases. } \overline{\mathrm{Pr}} \\
\text { Relative } \\
\end{array}$ \\
\hline 1500 & $\begin{array}{l}75,000 \mathrm{psi} \\
12.6 \mathrm{hrs} . \\
0.9 \mathrm{El}-4.0 \mathrm{RA}\end{array}$ & $\begin{array}{l}\operatorname{MC}\left(S-a_{0}=4.30\right) \\
M_{23} C_{6}\left(M S-a_{0}=10.67\right)\end{array}$ & 1500 & $\begin{array}{l}75,000 \text { psi } \\
109.4 \mathrm{hrs} . \\
6.2 \mathrm{EI}-7.0 \mathrm{RA}\end{array}$ & $\begin{array}{l}\mathrm{MC}\left(\mathrm{S}-\mathrm{a}_{0}=\right. \\
\mathrm{M}_{2} \mathrm{C}_{6}(\mathrm{MS}-\mathrm{a}\end{array}$ \\
\hline & $\begin{array}{l}60,000 \mathrm{psi} \\
412.4 \mathrm{hrs} \\
2.7 \mathrm{EI}-6.2 \mathrm{RA}\end{array}$ & $\begin{array}{l}M C\left(S-a_{0}=4.31\right) \\
M_{23} C_{6}\left(M S-a_{0}=10.70\right)\end{array}$ & & $\begin{array}{l}60,000 \mathrm{psi} \\
481.8 \mathrm{hrs} . \\
4.4 \mathrm{El}-7.8 \mathrm{RA}\end{array}$ & $\begin{array}{l}\mathrm{MC}\left(\mathrm{S}-\mathrm{a}_{0}=\right. \\
\mathrm{M}_{2} 3 \mathrm{C}_{6}(\mathrm{MS}-\end{array}$ \\
\hline & $\begin{array}{l}50,000 \mathrm{psi} \\
1515.7 \mathrm{hrs} \\
2.7 \mathrm{E1}-4.8 \mathrm{RA}\end{array}$ & $\begin{array}{l}M C\left(S-a_{0}=4.31\right) \\
M_{23} C_{6}\left(M S-a_{0}=10.72\right)\end{array}$ & & $\begin{array}{l}50,000 \text { psi } \\
1925.6 \text { hrs. } \\
5.3 \mathrm{El}-7.8 \mathrm{RA}\end{array}$ & $\begin{array}{l}\mathrm{MC}\left(\mathrm{S}-\mathrm{a}_{\mathrm{O}}=\right. \\
\mathrm{M}_{23} \mathrm{C}_{6}(\mathrm{MS}-\end{array}$ \\
\hline 1350 & $\begin{array}{l}100,000 \mathrm{psi} \\
11.3 \mathrm{hrs} . \\
1.8 \mathrm{El}-6.6 \mathrm{RA}\end{array}$ & $\begin{array}{l}M C\left(S-a_{0}=4.30\right) \\
M_{23} C_{6}\left(V W-a_{0}=10.72\right)\end{array}$ & 1350 & $\begin{array}{l}100,000 \mathrm{psi} \\
59.3 \mathrm{hrs} . \\
1.8 \mathrm{EI}-3.0 \mathrm{RA}\end{array}$ & $\begin{array}{l}\mathrm{MC}\left(\mathrm{S}-\mathrm{a}_{0}=\right. \\
\mathrm{M}_{23} \mathrm{C}_{6}(\mathrm{MW}-\end{array}$ \\
\hline & $\begin{array}{l}90,000 \mathrm{psi} \\
198.7 \mathrm{hrs} \\
1.8 \mathrm{E} 1 .-4.5 \mathrm{RA}\end{array}$ & $\begin{array}{l}\mathrm{MC}\left(\mathrm{S}-\mathrm{a}_{0}=4.31\right) \\
\mathrm{M}_{23} \mathrm{C}_{6}\left(\mathrm{MW}-\mathrm{a}_{0}=10.69\right)\end{array}$ & & $\begin{array}{l}90,000 \mathrm{psi} \\
411.5 \mathrm{hrs} \\
2.7 \mathrm{EI} .3 .9 \mathrm{RA}\end{array}$ & $\begin{array}{l}\mathrm{MC}\left(\mathrm{S}-\mathrm{a}_{\mathrm{O}}=\right. \\
\mathrm{M}_{23} \mathrm{C}_{6}\left(\mathrm{M}-\mathrm{a}_{\mathrm{c}}\right.\end{array}$ \\
\hline & & & & $\begin{array}{l}80,000 \text { psi } \\
2711.3 \text { hrs. } \\
4.4 \mathrm{E} .-6.3 \mathrm{RA}\end{array}$ & $\begin{array}{l}\mathrm{MC}\left(\mathrm{S}-\mathrm{a}_{0}=\right. \\
\mathrm{M}_{2} \mathrm{C}_{6}(\mathrm{MS}-\end{array}$ \\
\hline Notes & $\begin{aligned} \mathrm{S} & =\text { Strong } \\
\mathrm{MS} & =\text { Moderate Strong } \\
\mathrm{M} & =\text { Moderate }\end{aligned}$ & $\begin{aligned} \mathrm{MW} & =\text { Moderate Weak } \\
\mathrm{W} & =\text { Weak } \\
\mathrm{VW} & =\text { Very Weak } \\
a_{0} & =\text { in A units }\end{aligned}$ & & & \\
\hline
\end{tabular}


TABLE III

Chemical Analysis (Atomic Percent) of $\gamma^{\prime}$ Phase Extracted From As-Cast IN-73IX

\begin{tabular}{|c|c|c|c|c|c|c|c|c|}
\hline $\mathrm{Cr}$ & Co & Mo & $\mathrm{V}$ & $\mathrm{Ti}$ & $\mathrm{A} 1$ & $\mathrm{Ni}$ & $\begin{array}{r}\text { Vol \% } \\
\gamma^{\prime} \text { calc } \\
\end{array}$ & $\begin{array}{l}\text { Vol \% } \\
\gamma^{\prime} \text { obs }\end{array}$ \\
\hline .09 & 5.91 & .87 & .57 & 8.28 & 15.33 & 65.60 & 58.9 & 58.4 \\
\hline .03 & \pm .07 & \pm .01 & \pm .06 & \pm .53 & \pm .37 & \pm .21 & \pm 3.8 & \\
\hline
\end{tabular}


TABLE IV

$\gamma^{\prime}$ Composition and Vol Percent, Residual Matrix Composition, $\overline{\mathrm{N}}_{\mathrm{V}}$ for IN-73IX After Various Treatments

\begin{tabular}{|c|c|c|c|c|c|c|c|c|c|c|c|c|c|c|}
\hline \multirow[b]{2}{*}{ Treatment } & \multicolumn{9}{|c|}{ Chemical Composition - Atomic Percent } & \multirow{2}{*}{$\begin{array}{r}\text { Vol \% } \\
Y^{\prime} \mathrm{Calc} \\
\end{array}$} & \multirow{2}{*}{$\begin{array}{l}\text { Vol \% } \\
y^{\prime} \text { obs }\end{array}$} & \multirow[b]{2}{*}{$\overline{\mathbb{N}}_{V_{-}}$} & \multirow{2}{*}{\multicolumn{2}{|c|}{$\gamma^{\prime}: 1$}} \\
\hline & & $\mathrm{C}$ & $\mathrm{Cr}$ & $\mathrm{CO}$ & Mo & $\mathrm{V}$ & $\mathrm{Ti}$ & $\bar{A} I$ & $\mathrm{Ni}$ & & & & & \\
\hline \multirow[t]{2}{*}{ As Cast } & $\gamma^{\prime}$ & .00 & 3.06 & 5.84 & .87 & .62 & 7.75 & 15.69 & 66.17 & 58.9 & 58.4 & & & .079 \\
\hline & R.M.* & .00 & 19.75 & 15.20 & 2.08 & 1.50 & 0.00 & 3.79 & 57.58 & & & 2.07 & $\begin{array}{l}.81 \\
.613\end{array}$ & $\begin{array}{l}\mathrm{Ti} \\
.331\end{array}$ \\
\hline \multirow{2}{*}{$\begin{array}{l}1350^{\circ} \mathrm{F} / \\
2711.3 \text { hrs }\end{array}$} & $\gamma^{\prime}$ & .00 & 2.49 & 4.61 & 0.80 & 0.76 & 8.40 & 16.03 & 66.91 & 57.8 & 56.7 & & $\begin{array}{l}(\mathrm{Ni} \\
.892\end{array}$ & $\begin{array}{l}\text { Co } \\
.062\end{array}$ \\
\hline & R.M. & .00 & 18.55 & 15.88 & 2.05 & 1.16 & 0.00 & 4.75 & 57.61 & & & 2.04 & & $\begin{array}{l}\mathrm{Ti} \\
.336\end{array}$ \\
\hline \multirow{2}{*}{$\begin{array}{l}1500^{\circ} \mathrm{F} / \mathrm{h} \\
1925.6^{\mathrm{hrs}}\end{array}$} & $\gamma^{\prime}$ & .00 & 2.40 & 4.96 & 0.59 & 0.39 & 7.80 & 17.05 & 66.80 & 62.6 & 60.6 & & $\begin{array}{l}(\mathrm{Ni} \\
.890\end{array}$ & $\begin{array}{l}\text { Co } \\
.070\end{array}$ \\
\hline & R.M. & .00 & 20.74 & 16.68 & 2.57 & 1.89 & 0.00 & 1.48 & 56.64 & & & 1.97 & & $\begin{array}{l}\mathrm{Ti} \\
.312\end{array}$ \\
\hline \multirow{2}{*}{$\begin{array}{l}1800^{\circ} \mathrm{F} / \\
733.7 \mathrm{hrs}\end{array}$} & $\gamma^{\prime}$ & .00 & 2.30 & 5.17 & 0.50 & 0.58 & 10.62 & 15.28 & 65.55 & 45.6 & 49.4 & & \multirow{2}{*}{\multicolumn{2}{|c|}{$\left.\begin{array}{ll}(\mathrm{Ni} & \mathrm{Co} \\
.875 & .070 \\
(\mathrm{AI} & \mathrm{Ti} \\
.590 & .410\end{array}\right)$}} \\
\hline & R. M. & .00 & 14.88 & 12.71 & 2.02 & 1.24 & 0.00 & 8.09 & 61.06 & & & 2.10 & & \\
\hline
\end{tabular}

* R.M. = Residual Matrix 
TABLE V

Stress Rupture Properties of Alloy $713 \mathrm{C}$ and Alloy $713 \mathrm{LC}$

Alloy $713 \mathrm{C}$

Heat \# Heat Treatment Life (hrs) $1500^{\circ} \mathrm{F} / 40,000$ psi

74 As Cast

$74 \quad 2150^{\circ} \mathrm{F} / \mathrm{l} \mathrm{hr}+$ $1900^{\circ} \mathrm{F} / 4$ hrs

07 As Cast

$07 \quad 2150^{\circ} \mathrm{F} / \mathrm{lhr} \div$ $1900^{\circ} \mathrm{F} / 4 \mathrm{hrs}$

17 As Cast

$17 \quad 2150^{\circ} \mathrm{F} / \mathrm{l} \mathrm{hr}+$ $1900^{\circ} \mathrm{F} / 4 \mathrm{hrs}$
2182.7 hrs

8.0 Elong - 11.0 RA

$1554.0 \mathrm{hrs}$

3.6 Elong - $3.0 \mathrm{RA}$

\section{Al1oy 713IC}

1604.0 hrs

7.1 Elong - $8.4 \mathrm{RA}$

2505 hrs

3.6 Elong - 7.0 RA

$1862.7 \mathrm{hrs}$

16.0 Elong - 27.8 RA

$3648.6 \mathrm{hrs}$

12.0 Elong - $22.0 \mathrm{RA}$
Moderate

strong

NiI

Relative Amount of Sigma Present After Test

Strong

$\bar{N}_{V}(r$

2.1

2.1

NiI

2.0

2.0

NiI 


\section{TABLE VI}

$\gamma^{\prime}$ Composition, Vol $\% \gamma^{\prime}$, Residual Matrix Composition of Alloy $713 \mathrm{C}$ After Heat Treatment (Heat 85)

\begin{tabular}{|c|c|c|c|c|c|c|c|c|c|c|c|c|c|c|}
\hline Treatment & & $\frac{\text { Che }}{\text { C }}$ & $\frac{\text { nical }}{\mathrm{Cr}}$ & $\frac{m p o s}{M o}$ & $\frac{\text { tion }}{\mathrm{Cb}}$ & $\frac{\text { Atomi }}{\text { Al }}$ & $\frac{\text { Perc }}{\mathrm{T} i}$ & $\frac{2 t}{N \underline{i}}$ & $\begin{array}{c}\text { Vol \% } \\
\gamma^{\prime} \text { calc }\end{array}$ & $\begin{array}{l}\text { Vol \% } \\
\gamma^{\prime} \text { obs }\end{array}$ & $\overline{\mathbb{N}}_{\mathrm{J}}$ & $x^{\prime}$ & Fo & mula \\
\hline \multirow[t]{2}{*}{ As Cast } & $\gamma^{\prime}$ & .00 & 3.76 & 1.24 & 2.17 & 17.92 & 1.26 & 73.66 & \multirow[t]{2}{*}{50.7} & \multirow[t]{2}{*}{52.3} & & ( $\mathrm{Ni}$ & & \\
\hline & R.M.* & .00 & 23.36 & 3.86 & .00 & 6.12 & .31 & 66.30 & & & 2.20 & $\begin{array}{l}\dot{A} I \\
.717\end{array}$ & $\begin{array}{l}\mathrm{Cb} \\
.087\end{array}$ & $\begin{array}{l}\mathrm{Ti} \\
.050\end{array}$ \\
\hline \multirow{2}{*}{$\begin{array}{l}2150^{\circ} \mathrm{F} / \\
1 \mathrm{hr}\end{array}$} & $\gamma^{\prime}$ & .00 & 3.93 & 1.17 & 2.42 & 17.79 & 1.33 & 73.37 & \multirow[t]{2}{*}{45.6} & \multirow[t]{2}{*}{46.3} & & & $\mathrm{Cr}$ & Mo \\
\hline & R. M. & .00 & 23.12 & 3.90 & .00 & 6.21 & .50 & 66.27 & & & 2.21 & $\begin{array}{l}.81 \\
.712\end{array}$ & $\begin{array}{l}\mathrm{Cb} \\
.097\end{array}$ & $\begin{array}{l}\mathrm{Ti} \\
.053\end{array}$ \\
\hline \multirow{2}{*}{$\begin{array}{l}1900^{\circ} \mathrm{F} / \\
4 \mathrm{hrs}\end{array}$} & $\gamma^{\prime}$ & .00 & 3.73 & 1.21 & 2.49 & 17.95 & .1 .26 & 73.36 & \multirow[t]{2}{*}{44.3} & \multirow[t]{2}{*}{44.4} & & & $\begin{array}{l}\text { Cr } \\
.018\end{array}$ & $\begin{array}{l}\text { Mo } \\
.004\end{array}$ \\
\hline & R.M. & .00 & 23.39 & 3.87 & .00 & 6.05 & .30 & 66.40 & & & 2.19 & .718 & $\begin{array}{l}\mathrm{Cb} \\
.100\end{array}$ & $\begin{array}{l}\mathrm{Ti} \\
.051\end{array}$ \\
\hline \multirow{2}{*}{$\begin{array}{l}2150^{\circ} \mathrm{F} / 1 \mathrm{hr}+ \\
1900^{\circ} \mathrm{F} / \mathrm{h}^{\prime \prime} \mathrm{hrs}\end{array}$} & $\gamma^{\prime}$. & .00 & 3.85 & 1.15 & 2.45 & 18.04 & 1.30 & 73.20 & \multirow[t]{2}{*}{45.0} & \multirow[t]{2}{*}{45.3} & & \multirow{2}{*}{$\begin{array}{l}(\mathrm{Ni} \\
.976 \\
(\dot{\mathrm{A}} \mathrm{I} \\
.722\end{array}$} & \multirow{2}{*}{$\begin{array}{l}\mathrm{Cr} \\
.019 \\
\mathrm{Cb} \\
.098\end{array}$} & \multirow{2}{*}{$\begin{array}{l}\text { Mo } \\
.005 \\
\dot{T} i \\
.052\end{array}$} \\
\hline & R.M. & .00 & 23.26 & 3.94 & .00 & 5.95 & .26 & 66.60 & & & 2.18 & & & \\
\hline
\end{tabular}

* R.M. = ResiduaI Matrix 
TABLE VII

$x^{\prime}$ Composition and Vol \%, Residual Matrix Composition, $\overline{\mathbb{N}}_{\mathrm{V}}$ of Alloy 713LC

Heat 17

\begin{tabular}{|c|c|c|c|c|c|c|c|c|c|c|c|c|c|c|}
\hline \multirow[b]{2}{*}{ Treatment } & \multicolumn{8}{|c|}{ Chemical Composition - Atomic Percent } & \multirow{2}{*}{$\begin{array}{c}\text { Vol } \% \\
x^{\prime} \mathrm{Calc} \\
\end{array}$} & \multirow{2}{*}{$\begin{array}{l}\text { Vol } \% \\
x^{\prime} \text { obs } \\
\end{array}$} & \multirow{2}{*}{$\overline{\mathrm{N}}_{\mathrm{v}}$} & \multirow{2}{*}{\multicolumn{2}{|c|}{$\gamma^{\prime}$}} & \multirow{2}{*}{ Formul } \\
\hline & 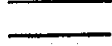 & $\mathrm{C}$ & $\mathrm{Cr}$ & Mo & $\mathrm{Cb}$ & Al & $\underline{\mathrm{Ti}}$ & $N_{i}$ & & & & & & \\
\hline As Cast & $\gamma^{\prime}$ & .00 & 3.44 & 1.18 & 2.44 & 17.66 & 1.05 & 74.25 & 19.8 & 50.2 & & $(\mathrm{Ni}$ & $\mathrm{Cr}$ & Mo \\
\hline & R.M.* & .00 & 22.86 & 3.88 & .00 & 6.60 & .27 & 66.39 & & & 2.21 & $\begin{array}{l}\text { A.1 } \\
.706\end{array}$ & $\begin{array}{l}\mathrm{Cb} \\
.098\end{array}$ & $\begin{array}{l}T i \\
.042\end{array}$ \\
\hline & & & & & & & & at 07 & & & & & & \\
\hline As Cast & $\gamma^{\prime}$ & .00 & 3.82 & 1.35 & 2.66 & 17.90 & 1.12 & 73.17 & 45.1 & 46.2 & & ${ }_{(\mathrm{Ni}}{ }_{976}$ & $\mathrm{Cr}$ & $\begin{array}{l}\text { Mo } \\
005\end{array}$ \\
\hline & R. M. & .00 & 20.24 & 3.53 & .00 & 7.41 & .47 & 68.35 & & & 2.16 & $\begin{array}{l}\text { (A1 } \\
.716\end{array}$ & $\begin{array}{l}\mathrm{Cb} \\
.106\end{array}$ & $\begin{array}{l}\mathrm{Ti} \\
.045\end{array}$ \\
\hline
\end{tabular}

* R.M. = Residual Matrix 


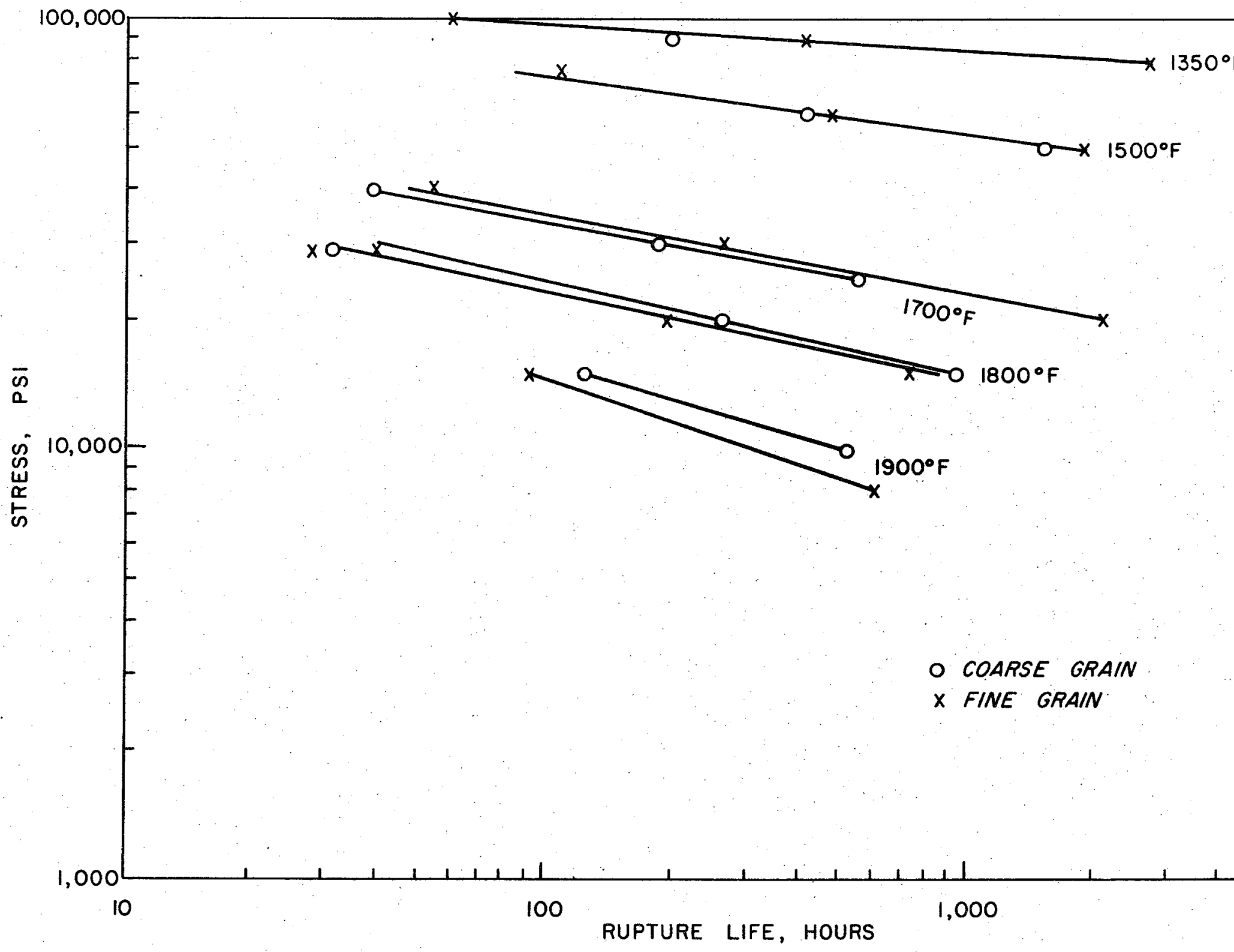

FIGURE I-STRESS RUPTURE RESULTS ON IN-73IX, AS-CAST CONDIT 


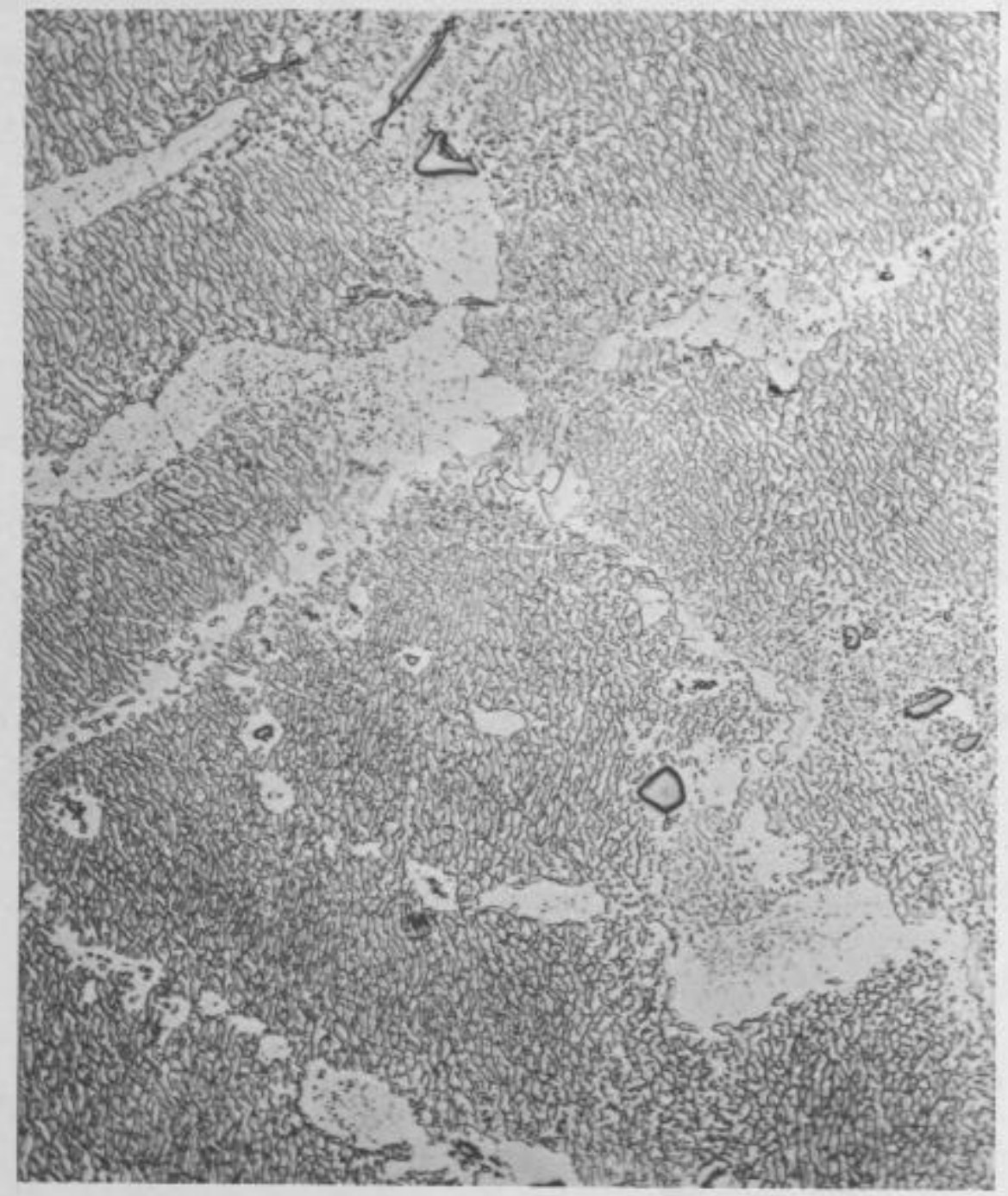

Fine grain - $1800^{\circ} \mathrm{F} / 733.7$ hrs. $500 \mathrm{x}$ (a)

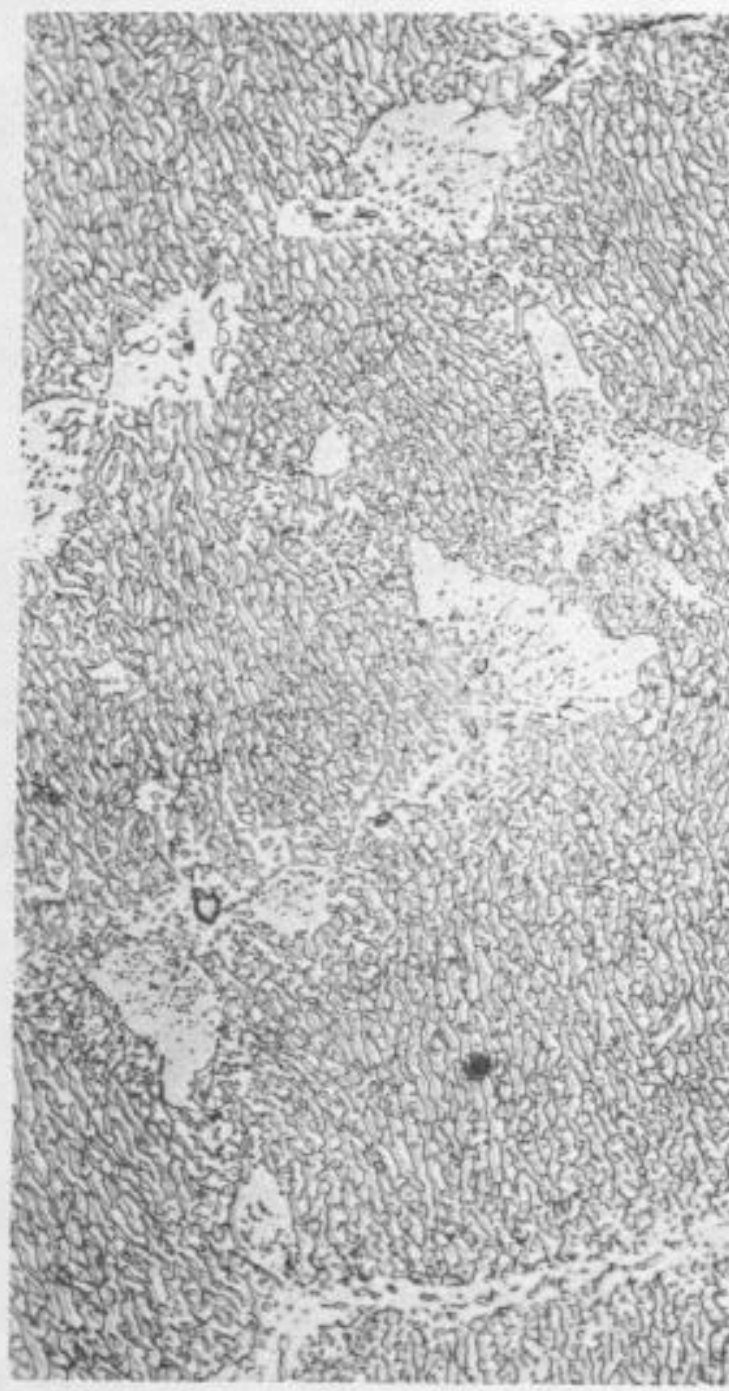

Coarse grain - $1800^{\circ} \mathrm{F} / 942$

(b) 


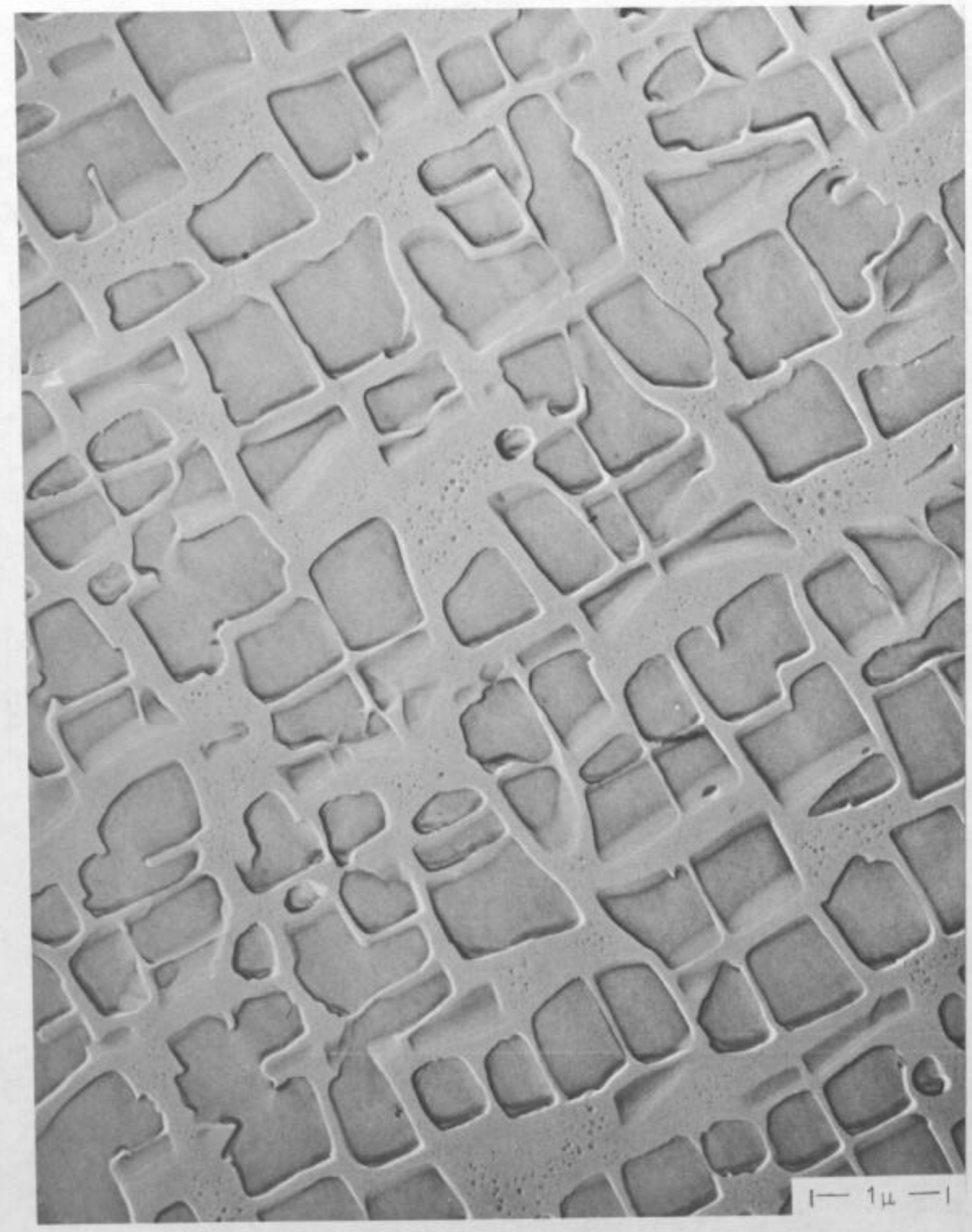

Figure 3

As Cast Microstructure of IN $731 \mathrm{X}$ 


\section{As Cast}

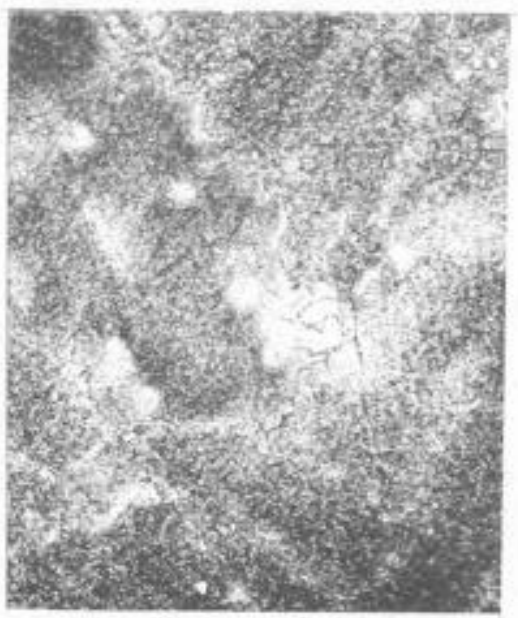

$2150^{\circ} \mathrm{F} / 1 \mathrm{hr}$.

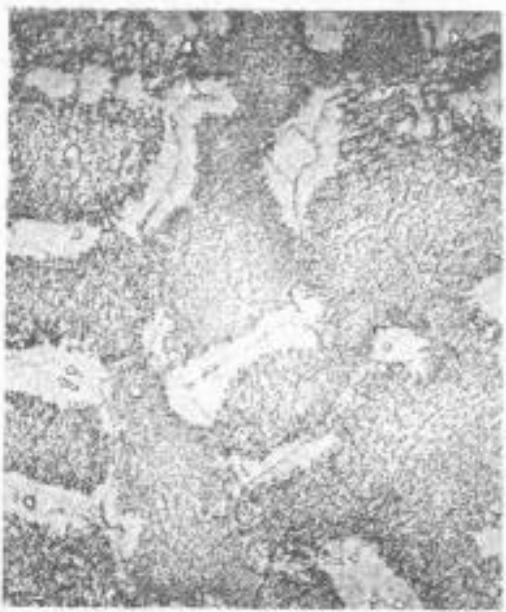

$1900^{\circ} \mathrm{F} / 4 \mathrm{hrs}$.

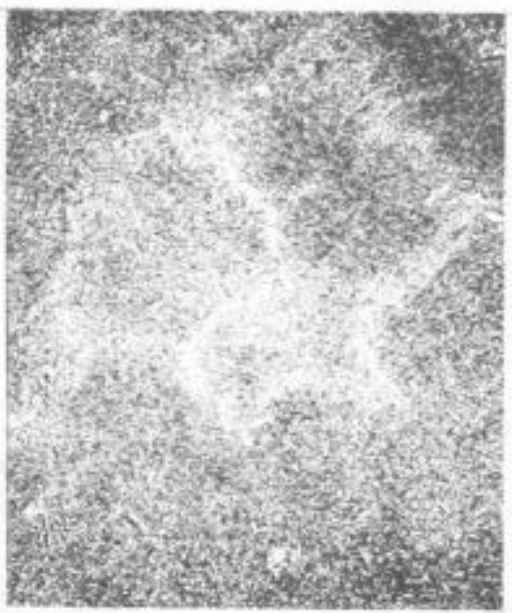

Phases Present and Relative Abundances* in Electrolytically Extracted Residue

$\vec{\circ}$

$$
\begin{gathered}
\frac{2150^{\circ} \mathrm{F} / 1 \mathrm{hr} .}{\operatorname{MC}\left(\mathrm{S}-\mathrm{a}_{0}=4.39\right)} \\
\operatorname{MeC}\left(\bar{W}-\mathrm{a}_{0}=11.10\right)
\end{gathered}
$$

$$
\begin{aligned}
& 1900^{\circ} \mathrm{F} / 4 \mathrm{hrs} . \\
& \mathrm{MC}\left(\mathrm{S}-\mathrm{a}_{0}=4.39\right) \\
& \left.\mathrm{MeC}_{8} \mathrm{~W}-\mathrm{A}_{0}=10.86-11.13\right) \\
& \mathrm{M}_{2} \mathrm{C}_{6}\left(\mathrm{MS}-\mathrm{a}_{0}=10.72\right)
\end{aligned}
$$

* $\quad \mathrm{S}=$ Strong

MS = Moderate Strong

$\mathrm{W}=$ Weak

$a_{0}=\operatorname{In} \AA$ Units 


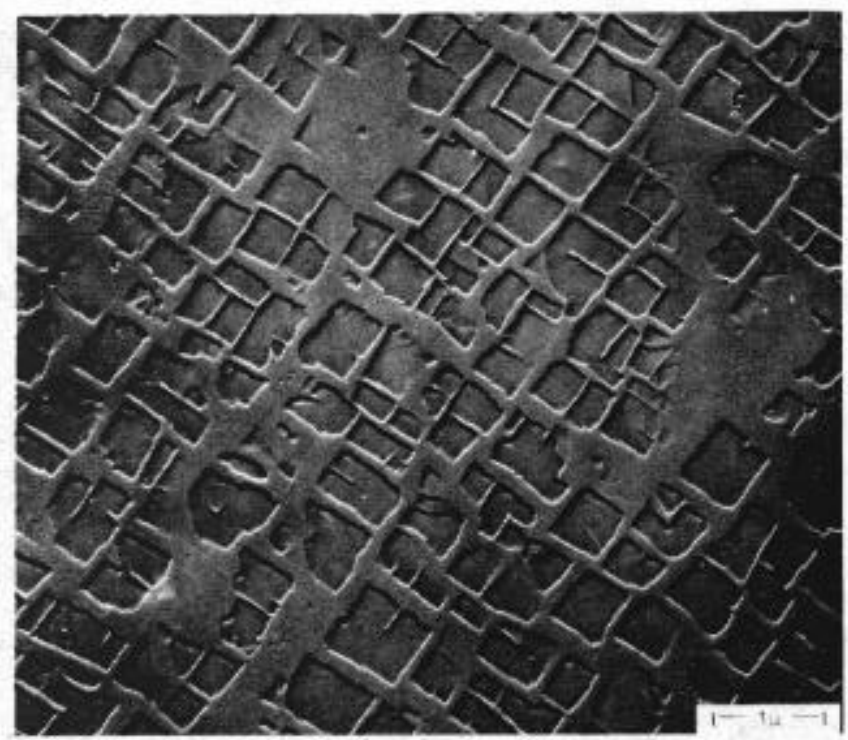

As Cast Area(a)

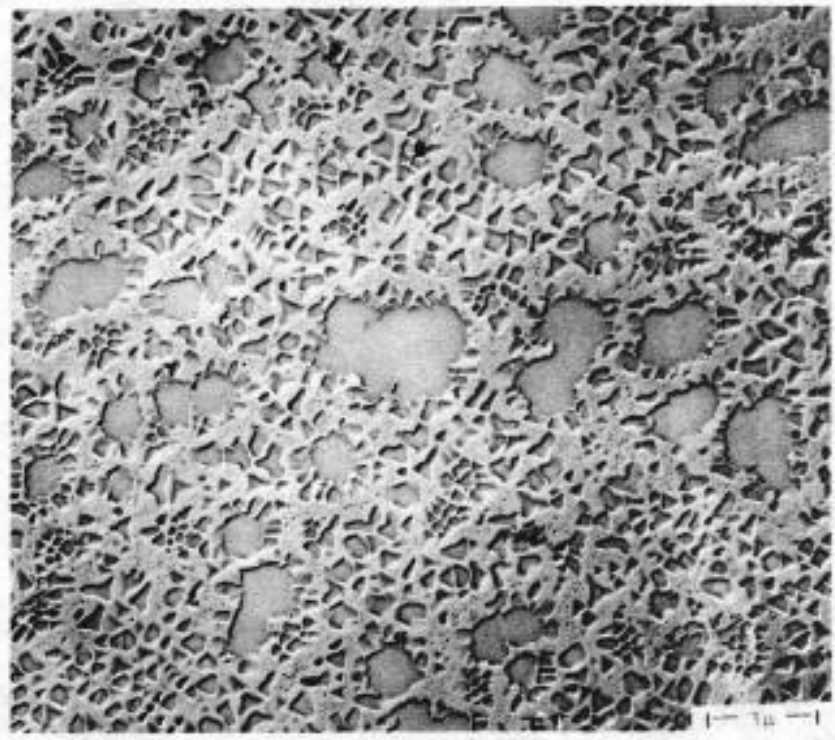

$2150^{\circ} \mathrm{F} / 1 \mathrm{hr}$.

Area(b)

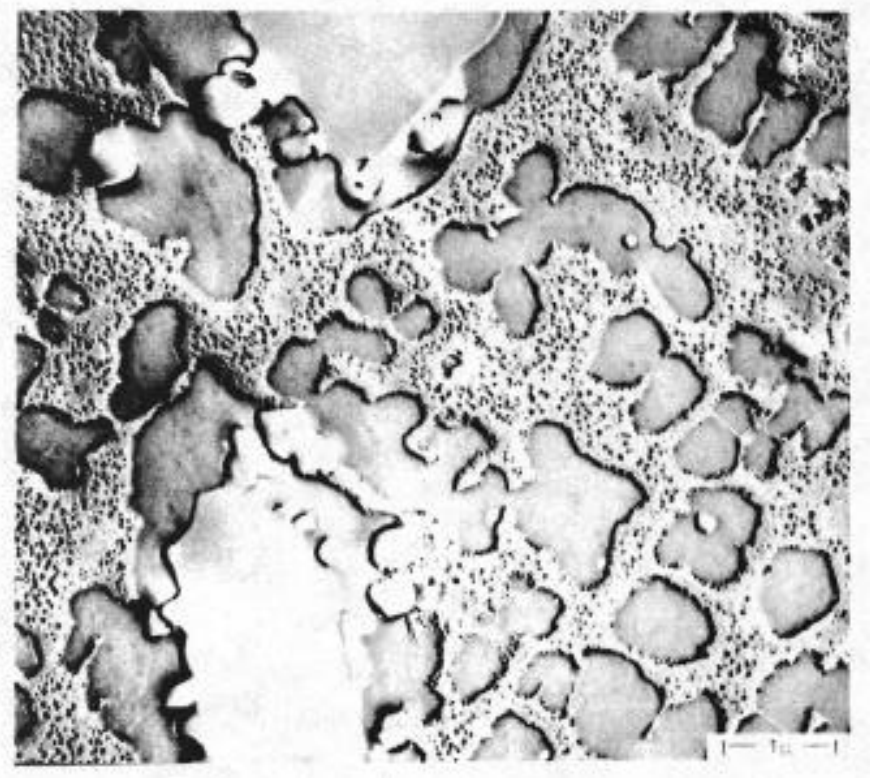

$2150^{\circ} \mathrm{F} / \mathrm{l} \mathrm{hr}$. Area(c)

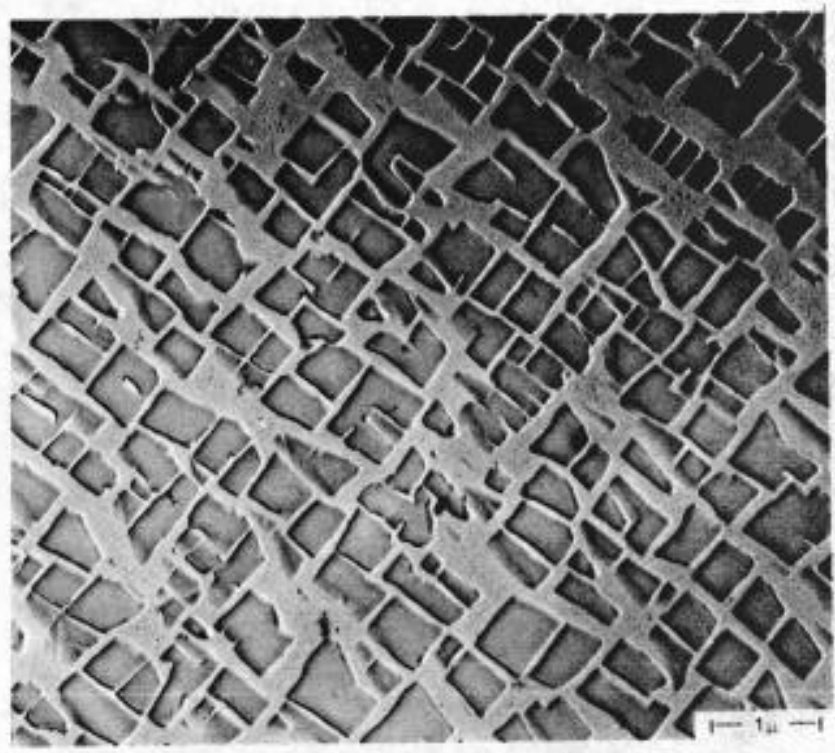

$2150^{\circ} \mathrm{F} / \mathrm{l} \mathrm{hr} . \quad$ Area(d)

Figure 5

Microstructure of Alloy $713 \mathrm{C}$

After Heat Treatment (Heat 74) 


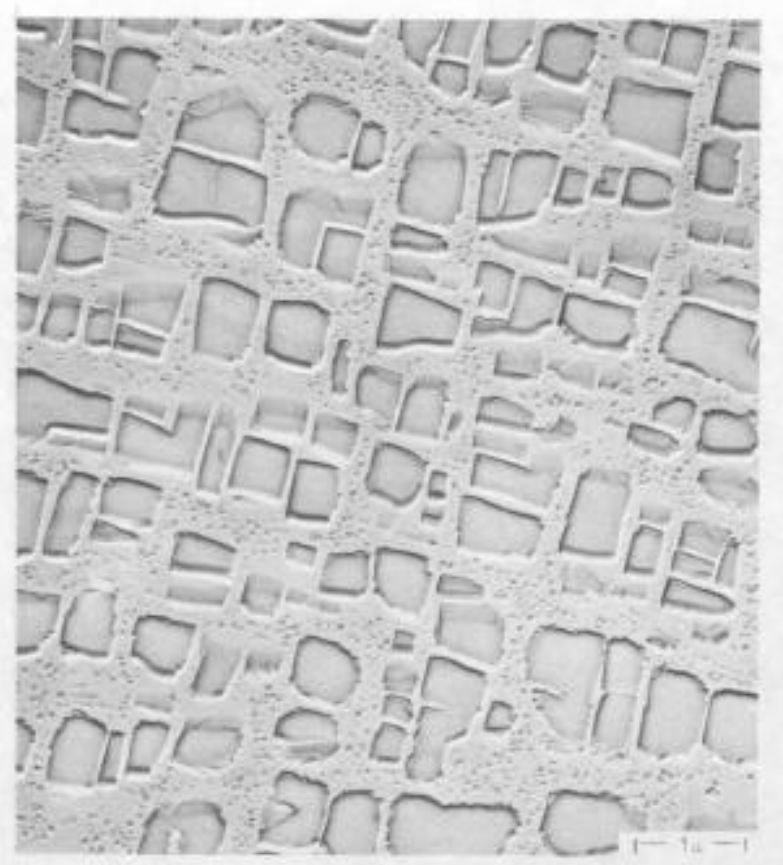

Area(a)

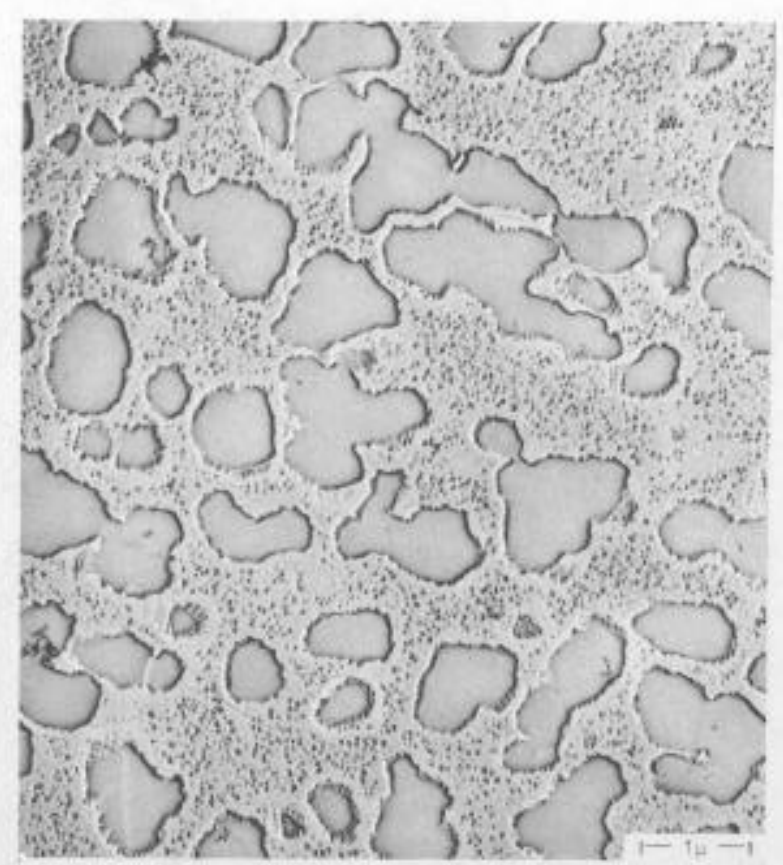

Area(b)

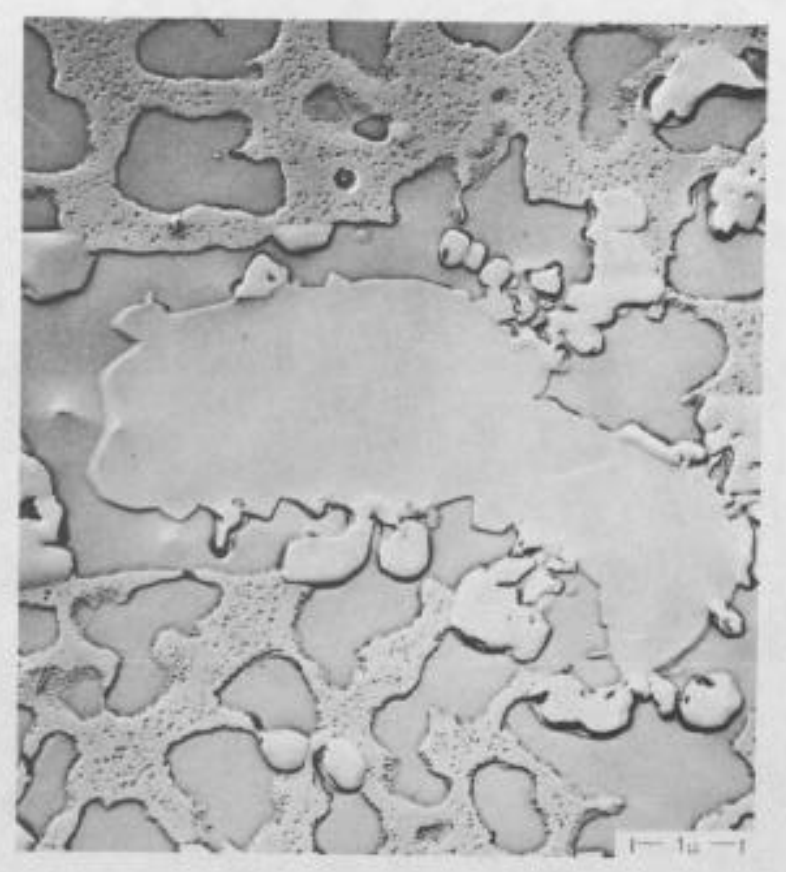

$$
\text { Area(c) }
$$

Figure 6

Microstructure of Alloy $713 \mathrm{C}$ After $1900^{\circ} \mathrm{F} / 4 \mathrm{hrs}$. (Heat 74 ) 

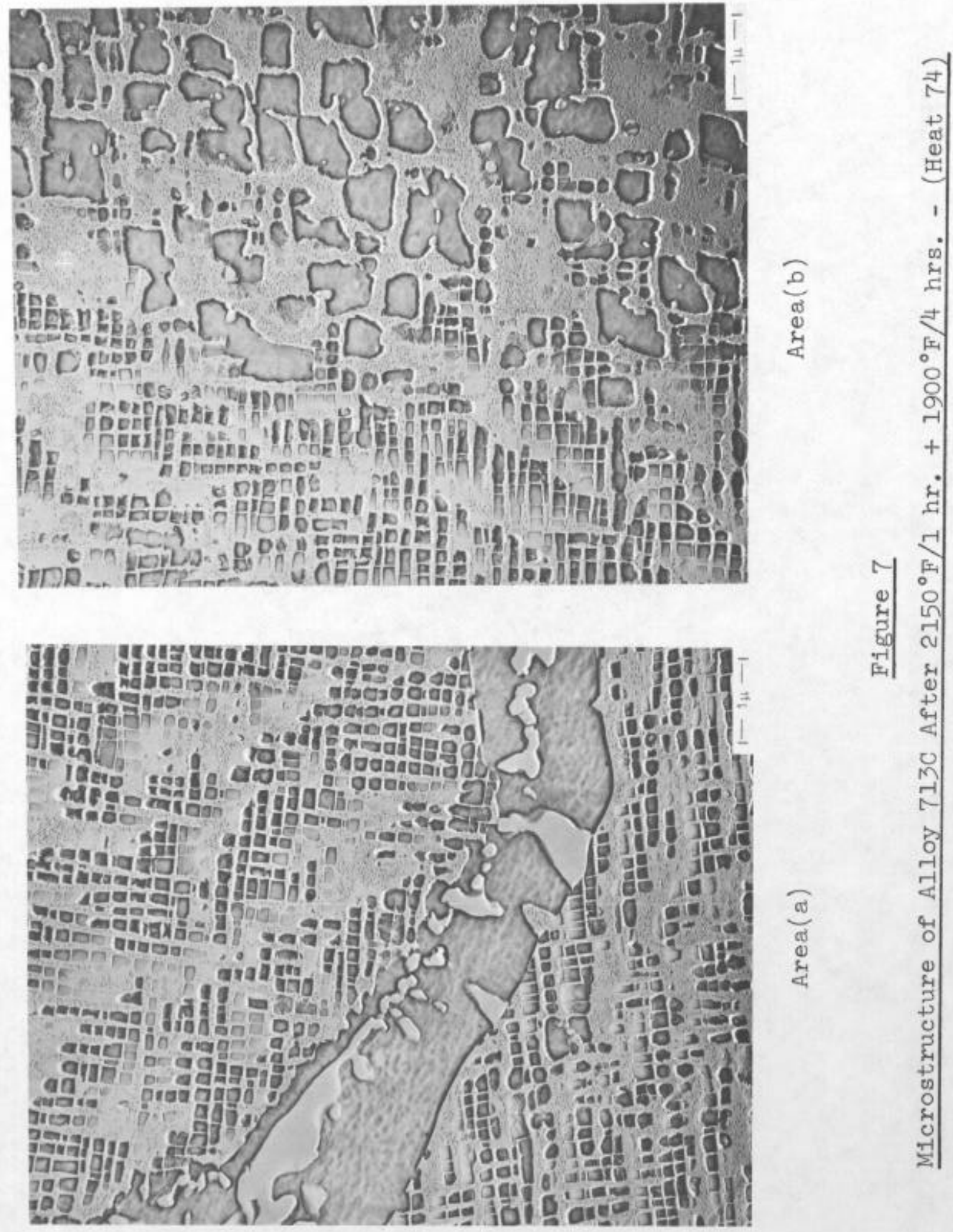
As Cast

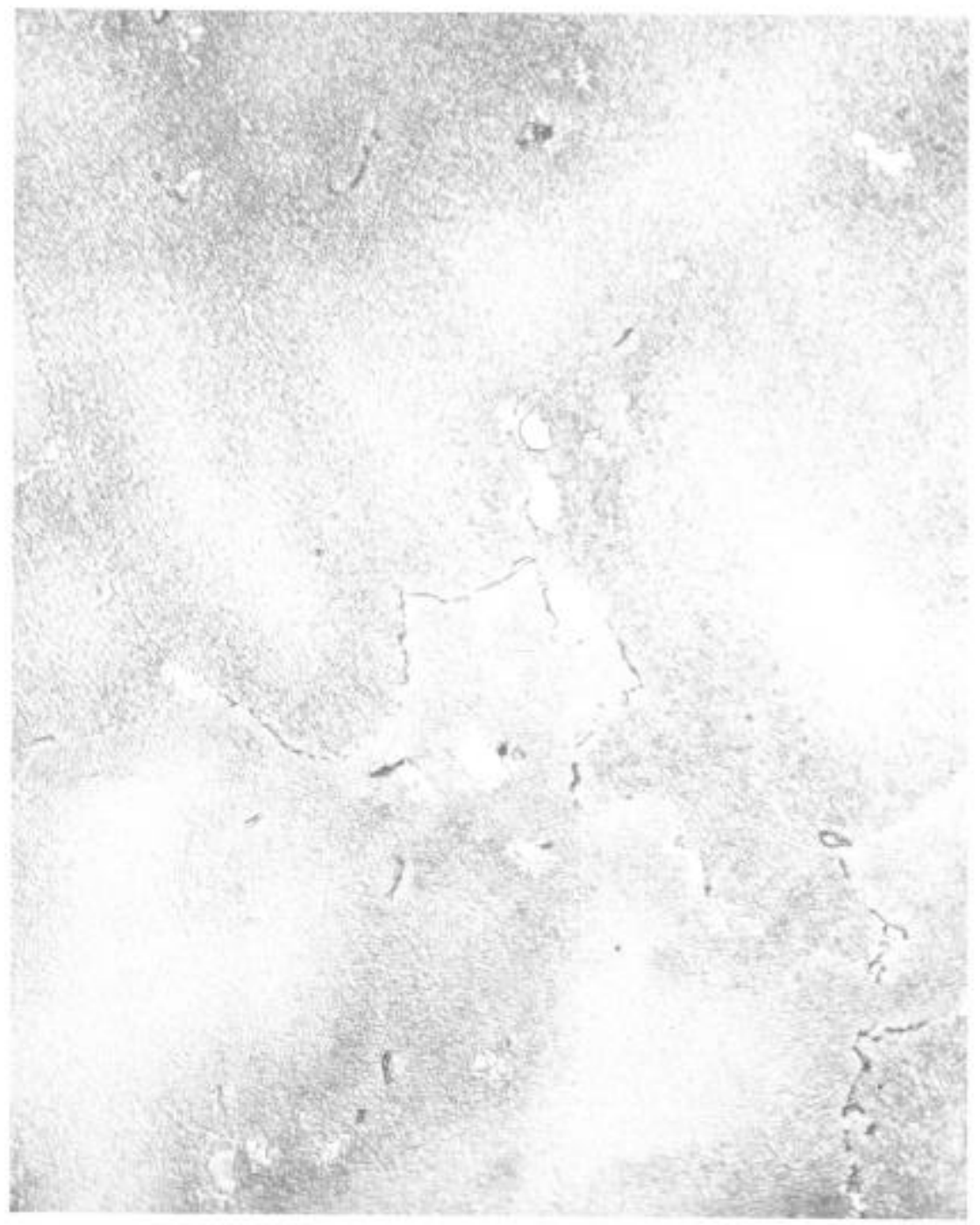

$2150^{\circ} \mathrm{F} / 1 \mathrm{hr} .+190$

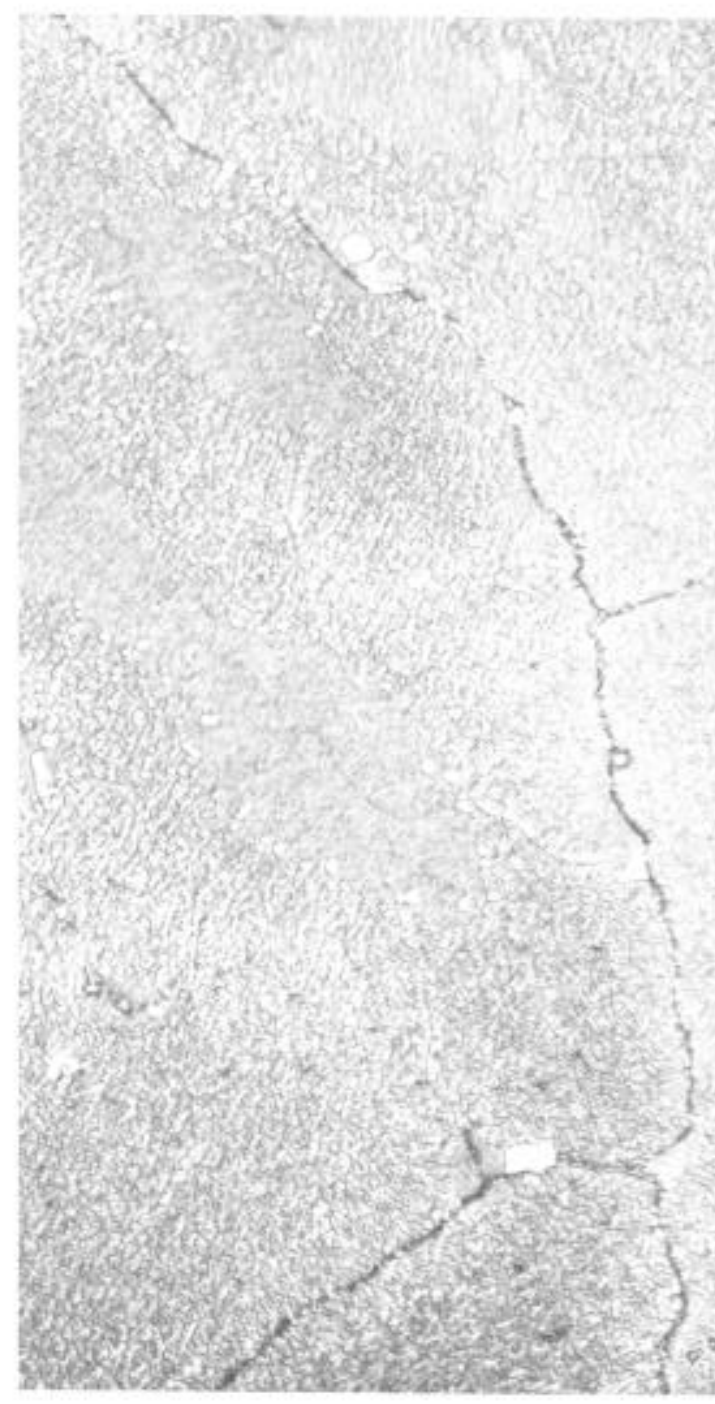

Figure 8

Microstructure of A110y 713LC After Heat Treatment(500X)- (Heat 17 


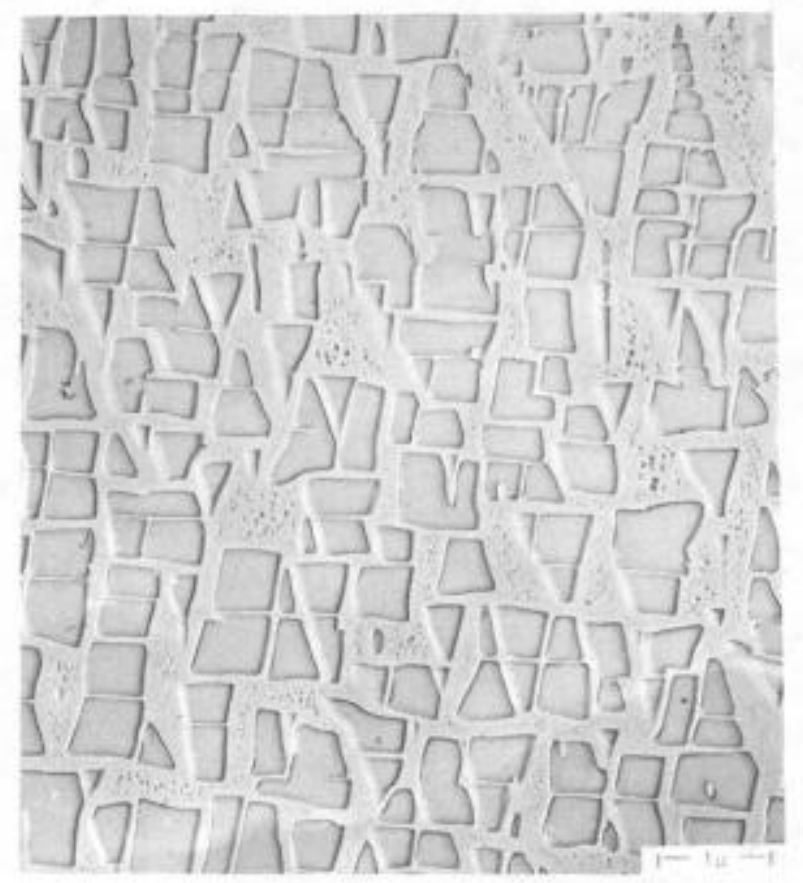

$\operatorname{Area}(\mathrm{a})$

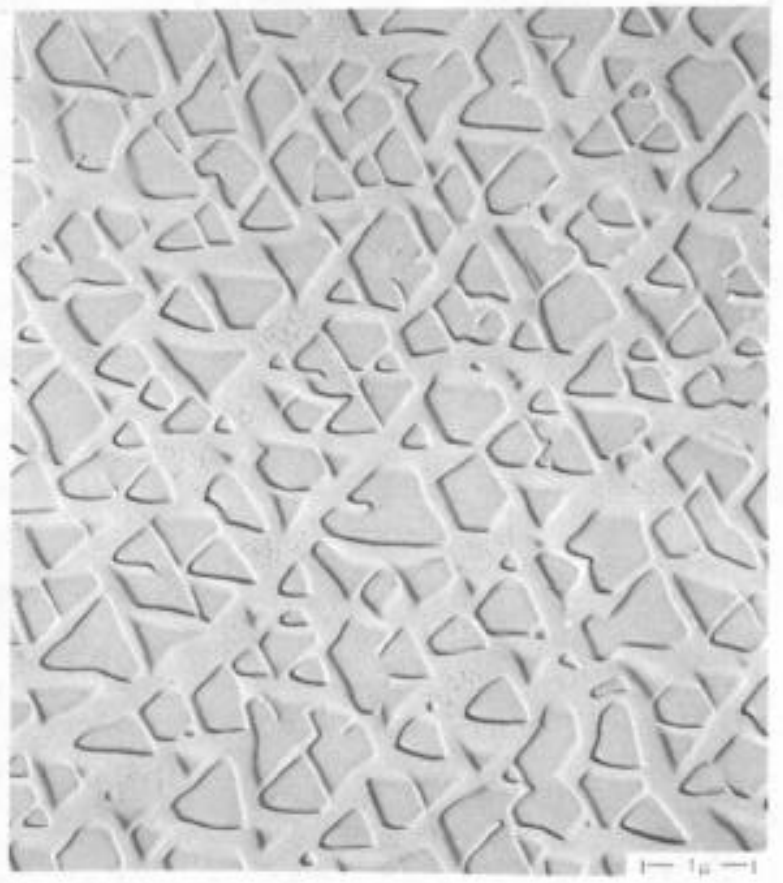

$\operatorname{Area}(\mathrm{b})$

$2150^{\circ} \mathrm{F} / \mathrm{l} \mathrm{hr} .+1900^{\circ} \mathrm{F} / 4 \mathrm{hrs}$.

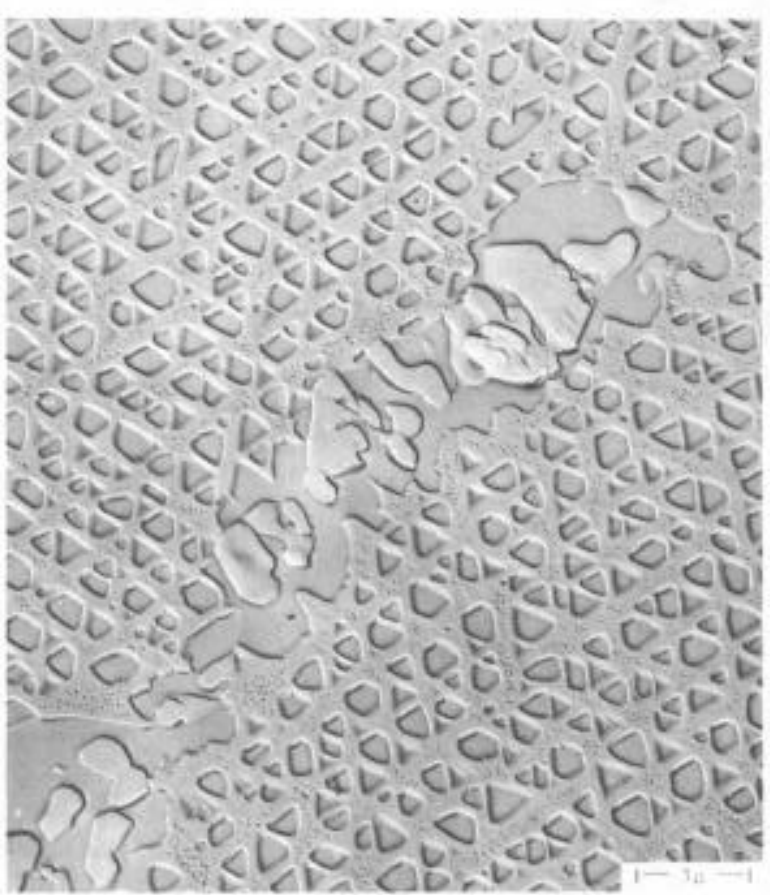

$\operatorname{Area}(\mathrm{c})$

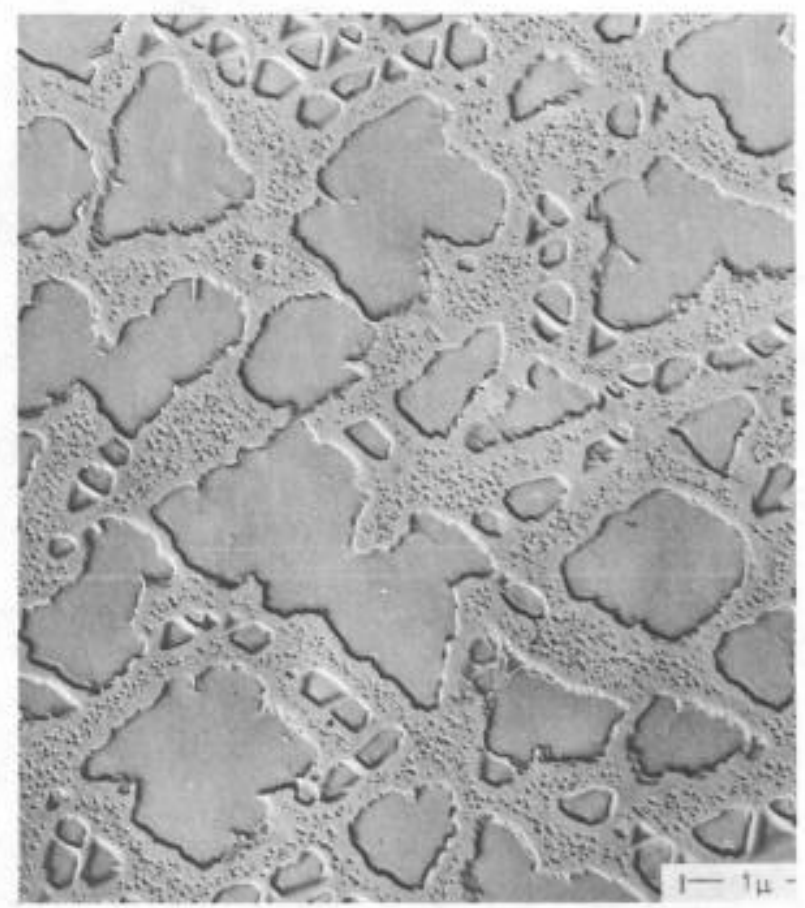

Area(d)

Figure 9

Microstructure of Alloy 713LC After Heat Treatment (Heat 17) 


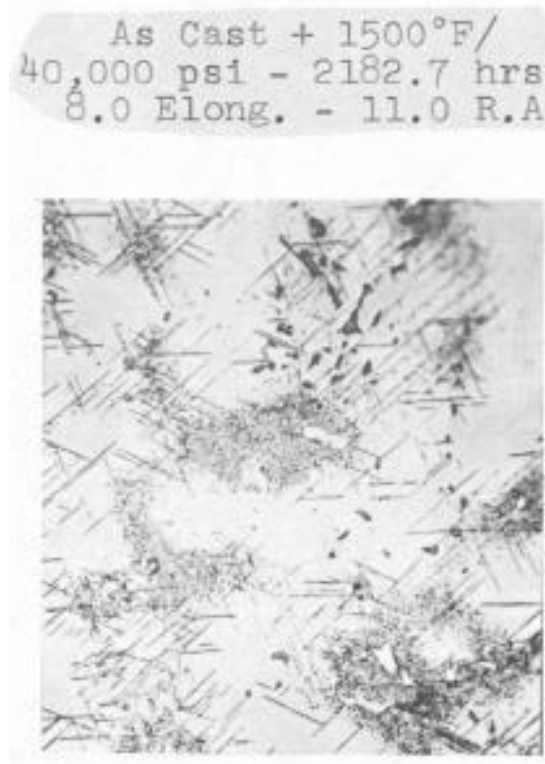

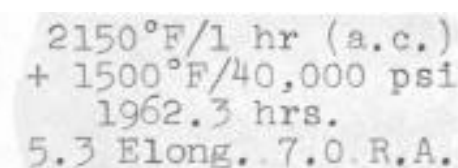

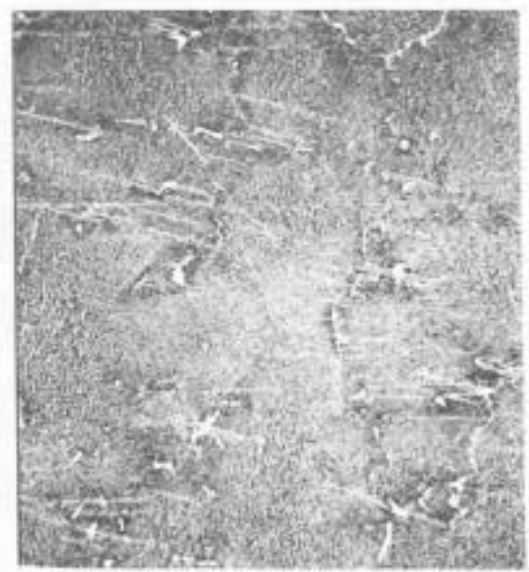

$1900^{\circ} \mathrm{F} / 4 \operatorname{hrs}($ a.c.)

$+1500^{\circ} \mathrm{F} / 40,000 \mathrm{ps} 1$ 1780.6 hrs.

4.0 Elong. 4.5 R. A.

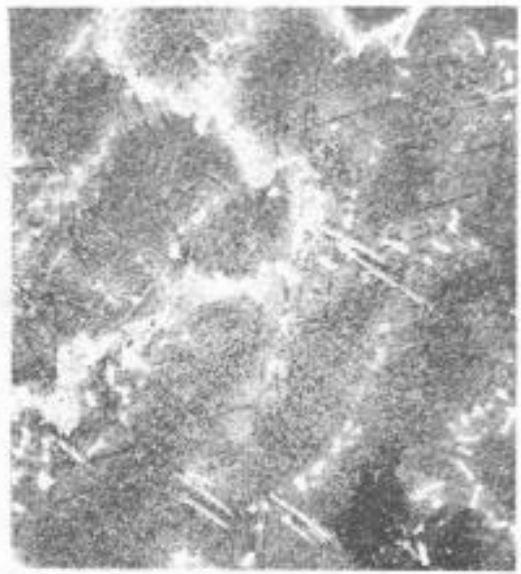

$2150^{\circ} \mathrm{F} / \mathrm{J}$

(a.c

Phases Present and Relative Abundances* in Electrolytically Extracted Resi

$\operatorname{MC}\left(\mathrm{S}-\mathrm{a}_{0}=4.39\right)$

$\mathrm{M}_{23} \mathrm{C}_{6}\left(\mathrm{MS}-\mathrm{a}_{0}=10.73\right)$

$\sigma\left(s-a_{0}=8.94\right)$

$c / a=.517)$

$M_{6} C\left(M W-a_{0}=10 \cdot 86-11.14\right)$

$$
\begin{aligned}
\operatorname{MC}\left(S-a_{0}\right. & =4.39) \\
M_{2} C_{6}\left(M S-a_{0}\right. & =10.71) \\
\sigma\left(M S-a_{0}\right. & =8.94) \\
c / a & =.517)
\end{aligned}
$$$$
M_{6} C\left(M W-a_{0}=10.93\right)
$$

$$
\begin{aligned}
\operatorname{MC}\left(S-a_{0}\right. & =4.39) \\
M_{2} C_{6}\left(M S-a_{0}\right. & =10.73) \\
\sigma\left(M S-a_{0}\right. & =8.94) \\
c / a & =1.517) \\
M_{6} C\left(M W-a_{0}\right. & =10.88- \\
& 11.12)
\end{aligned}
$$

\footnotetext{
* $\mathrm{S}=$ Strong

MS $=$ Moderate Strong

MW = Moderate Weak

$\mathrm{W}=$ Weak

$a_{0}=$ In $\AA$ Units
} 


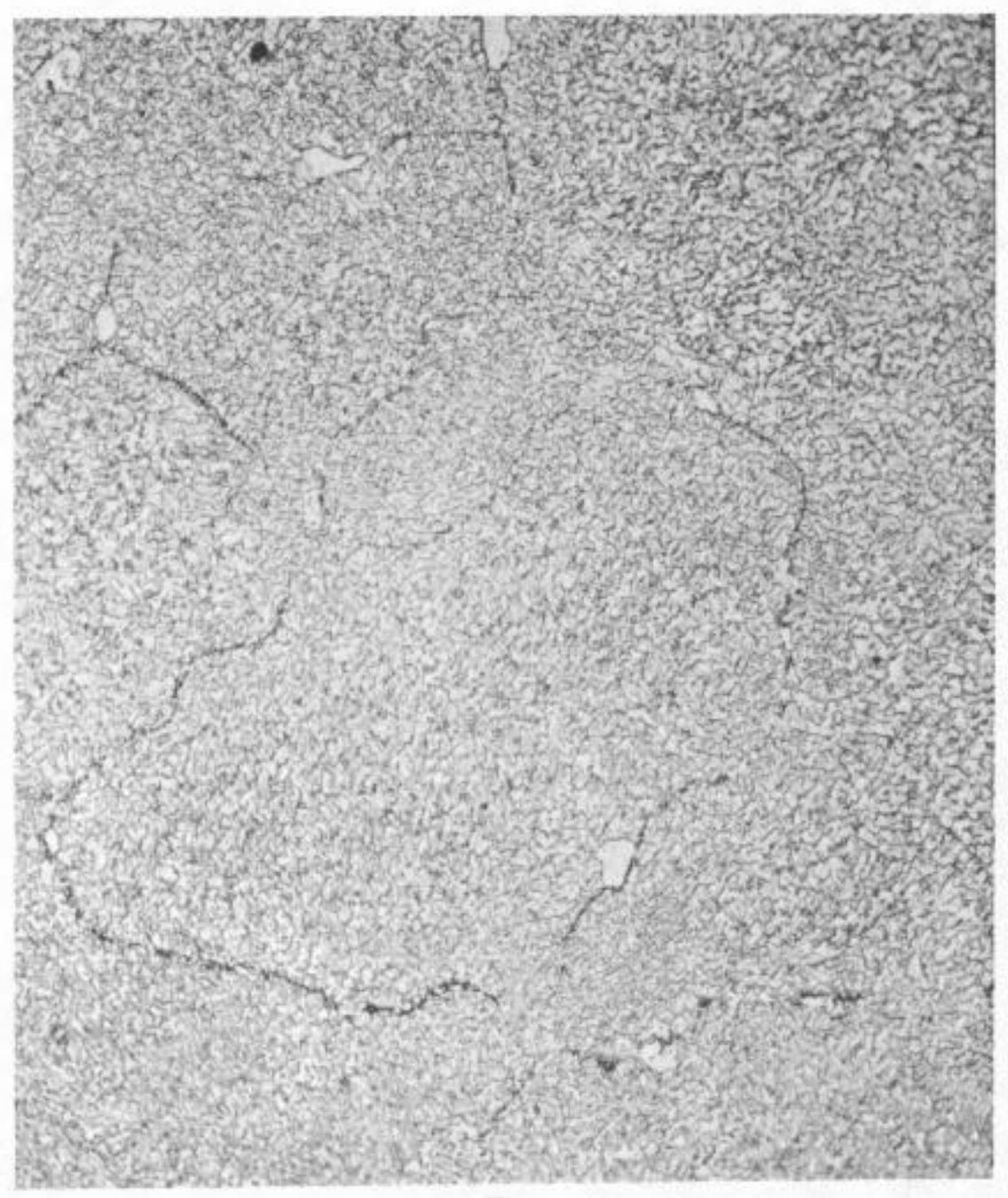

Figure 11

Microstructure of Alloy $713 \mathrm{LC}\left(500 \mathrm{X}\right.$ ) After $2150^{\circ} \mathrm{F} / \mathrm{l} \mathrm{hr} .+1900^{\circ} \mathrm{F} /$ 4 hrs. (a.c.) $+1500^{\circ} \mathrm{F} / 40,000 \mathrm{psi}-3648.6$ hrs. 12.0 Elong. - 22.0 R.A. 


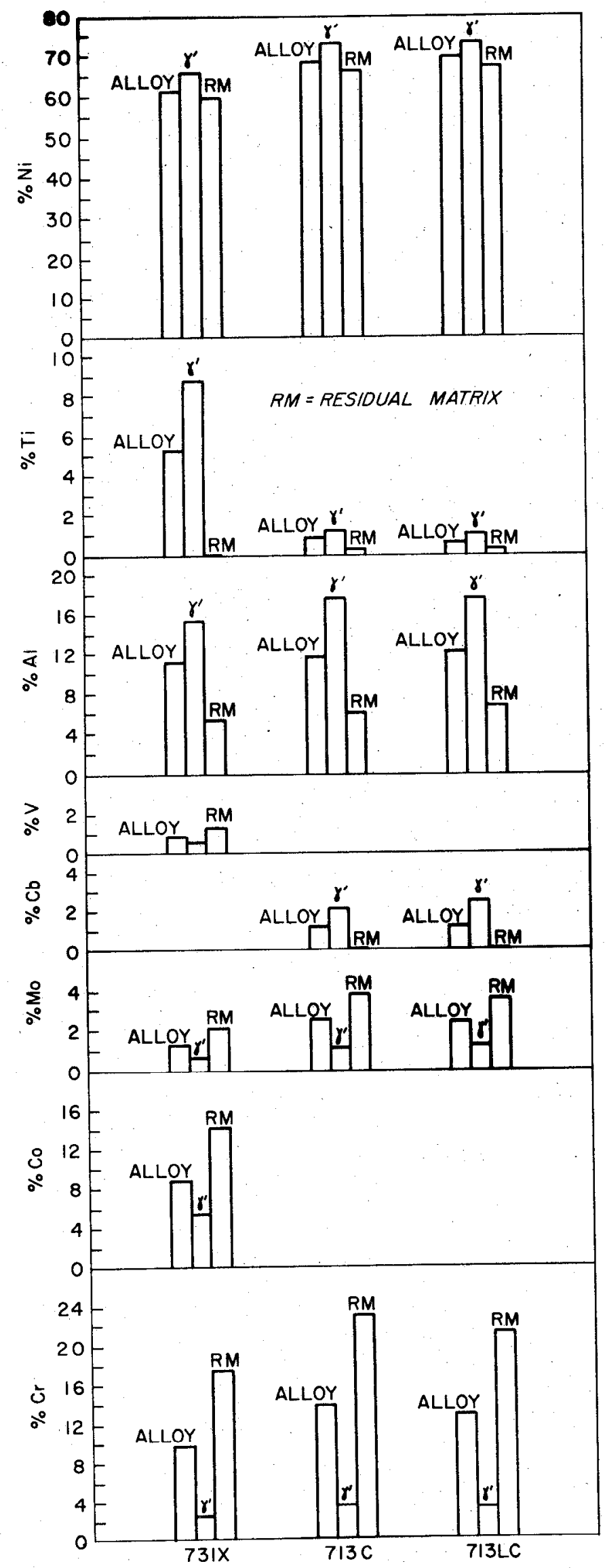

FIGURE 12 -PARTITIONING OF ALLOY ELEMENTS BETWEEN $\gamma^{\prime}$ AND RESIDUAL MATRIX FOR IN-73IX. ALLOY 7I3C AND ALLOY 7I3LC. 


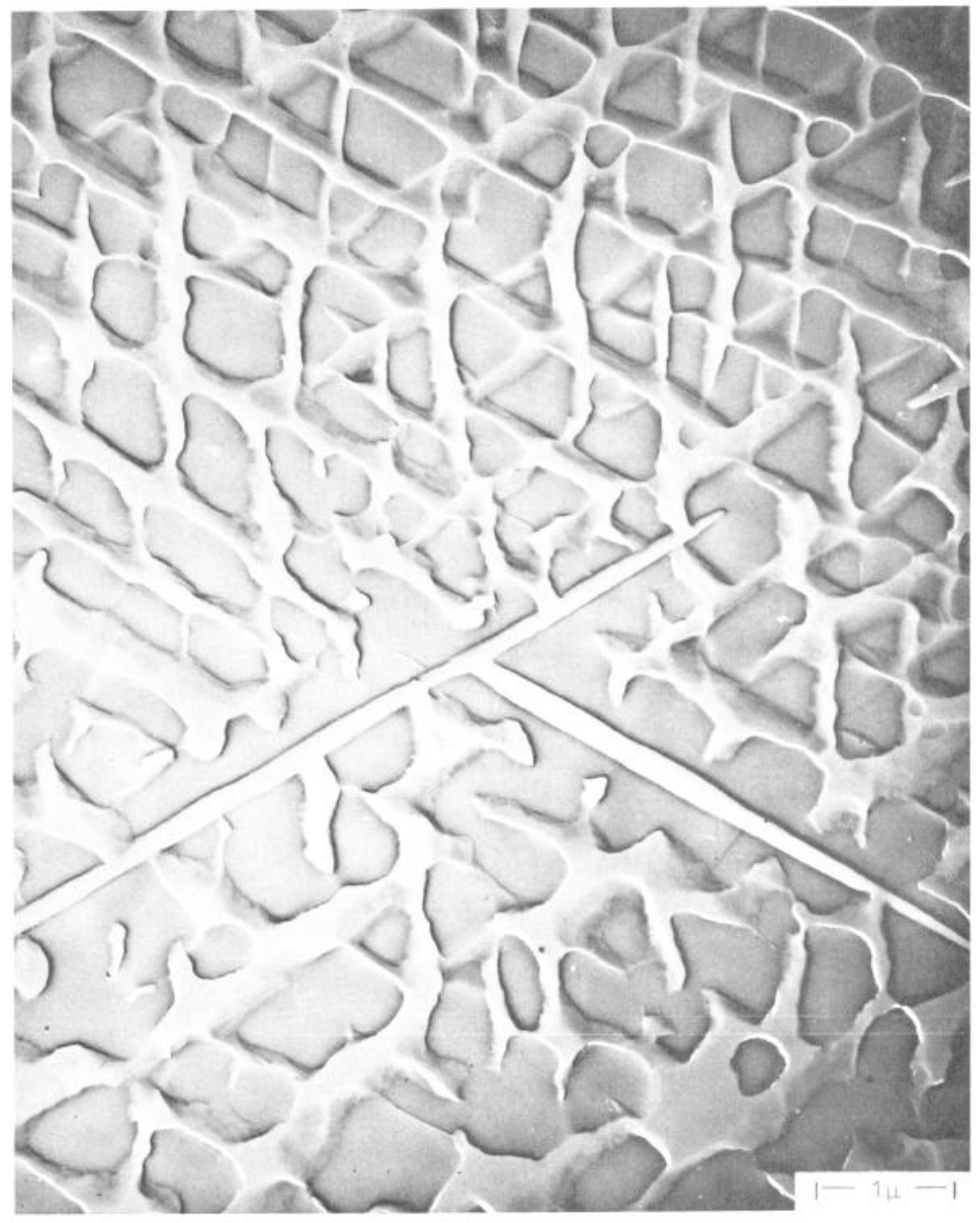

Figure 13

Sigma Formation in A110y $713 \mathrm{C}$ - Heat 74 - 2182.7 hrs. $/ 40,000 \mathrm{psi} / 1500^{\circ} \mathrm{F}$ 